\title{
17. NEOGENE SILICEOUS SEDIMENTS AND ROCKS OFF SOUTHERN CALIFORNIA AND BAJA CALIFORNIA, DEEP SEA DRILLING PROJECT LEG 631
}

\author{
V. I. Grechin, Geological Institute, U.S.S.R. Academy of Sciences, Moscow, U.S.S.R. \\ Kenneth A. Pisciotto, Deep Sea Drilling Project, Scripps Institution of Oceanography, La Jolla, California \\ John J. Mahoney, Geologic Research Division, Scripps Institution of Oceanography, La Jolla, California \\ and \\ S. N. Gordeeva, Geological Institute, U.S.S.R. Academy of Sciences, Moscow, U.S.S.R.
}

\begin{abstract}
The basal parts of Neogene diatomaceous deposits encountered off Southern California and Baja California during Leg 63 of the Deep Sea Drilling Project are diagenetically altered to chert, porcellanite, and siliceous mud rock. This depth-related lithologic trend coincides principally with mineral transformation of opal-A to opal-CT. At DSDP Site 471, off Baja California, the boundary between the opal-A zone and the underlying opal-CT diagenetic zone corresponds to a pronounced bottom-parallel seismic reflector that can be traced at least $80 \mathrm{~km}$ to the northwest along the coast of Baja California. At DSDP Sites 467 and 469 in the outer California Continental Borderland and at Site 471 the $\mathrm{d}(101)$-spacing of opal-CT decreases from about 4.10-4.12 $\AA$ to about $4.07 \AA$ with increasing depth of burial. Chemical analyses and X-ray diffraction of some sedimentary rocks below the opal-CT zones at Sites 467 and 471 show significant amounts of quartz, suggesting the presence of underlying quartz diagenetic zones. Using present thermal gradients and measured depths of burial, the approximate range in the present subsurface temperature of the opal-A to opal-CT transition at Leg 63 sites is $13^{\circ} \mathrm{C}$ to $52^{\circ} \mathrm{C}$. The depth to this transition is generally shallower at those sites in areas of high present thermal gradients.

The vertical sequences of facies encountered at Leg 63 sites are diagenetically and lithologically similar to some Neogene sequences in California, the Bering Sea, Kamchatka, Sakhalin, Japan, Peru, and Baja California. In contrast, Miocene quartz chert and spherulitic jasper intercalated with diabase and pillow basalt at Sites 469 and 471 probably represent small accumulations of thermally altered siliceous sediments deposited on active volcanic crust. Similar cherts occur in igneous rocks in the Franciscan complex in California and other Mesozoic sequences in the northwestern Cordillera.
\end{abstract}

\section{INTRODUCTION}

Neogene diatomaceous deposits are a widespread lithofacies in the marginal Pacific region (Orr, 1972; Ingle, 1973; Garrison, 1976; Ingle et al., 1978). In many areas burial diagenesis has transformed the basal parts of these opaline sediments to dense and brittle cherts, porcellanites, and siliceous mudrocks, the well-documented accompanying mineralogic progression being amorphous biogenic opal (opal-A) $\rightarrow$ cristobalitic silica (opal-CT) - microcrystalline quartz (Takahashi, 1922; Bramlette, 1946; Mizutani, 1970; Murata and Larson, 1975; Garrison et al., 1975; Grechin, 1976; Kastner, 1976; Mitsui and Taguchi, 1977; Hein et al., 1978; Iijima and Tada, in press). Experimental work indicates that time, temperature and geochemical environment are important factors controlling the pathways and rates of successive silica transformations (Mizutani, 1966, 1967, 1970; Ernst and Calvert, 1969; Kastner et al., 1977). Both in nature and in the laboratory the mineralogic zones overlap considerably. Within the cristobalitic zone the d(101)-spacing of opal-CT, as determined by $\mathrm{X}$-ray diffraction (XRD), sometimes displays a shift to progressively lower values with increasing diagenesis, a relationship useful for estimating past thermal and burial histories of siliceous rocks at specific localities

\footnotetext{
${ }^{1}$ Initial Reports of the Deep Sea Drilling Project, Volume 63.
}

(Murata and Nakata, 1974; Murata and Larson, 1975; Murata and Randall, 1975; Mitsui and Taguchi, 1977; Mizutani, 1977; Hein et al., 1978; Isaacs, 1979; Pisciotto, 1978, 1979; Murata et al., 1969; Iijima and Tada, in press).

During Leg 63 of the Deep Sea Drilling Project we encountered additional occurrences of Neogene (mostly middle to upper Miocene) diatomaceous and siliceous rocks in the outer California Continental Borderland and off Baja California (Fig. 1). This paper describes the distribution, associated lithofacies, and diagenesis of these deposits. In addition, we briefly compare the occurrences of these silica minerals with other diagenetic modifications of the sediments at each drill site (i.e., lithification and other authigenic mineral occurrences). We also discuss similarities in lithofacies and diagenesis between these sediments and coeval sequences in nearby onshore areas and elsewhere around the Pacific margin.

\section{TERMS AND METHODS}

This report follows Jones and Segnit's (1971) terms for opaline silica: opal- $\mathrm{A}=$ amorphous biogenic opal and opal-CT $=$ "disordered" $\alpha$-cristobalite and $\alpha$-tridymite derived largely from biogenic opal-A. Following Taliaferro (1934), Bramlette (1946), Murata and Larson (1975), Keene (1975), and Isaacs (1980), we restrict the usages of the terms chert and porcellanite to reflect textures, adding the specific silica mineralogy when known. Thus chert is a hard, conchoidally fracturing, cryptocrystalline sedimentary rock with semivitreous, vitreous, or waxy luster, consisting dominantly of silica; 


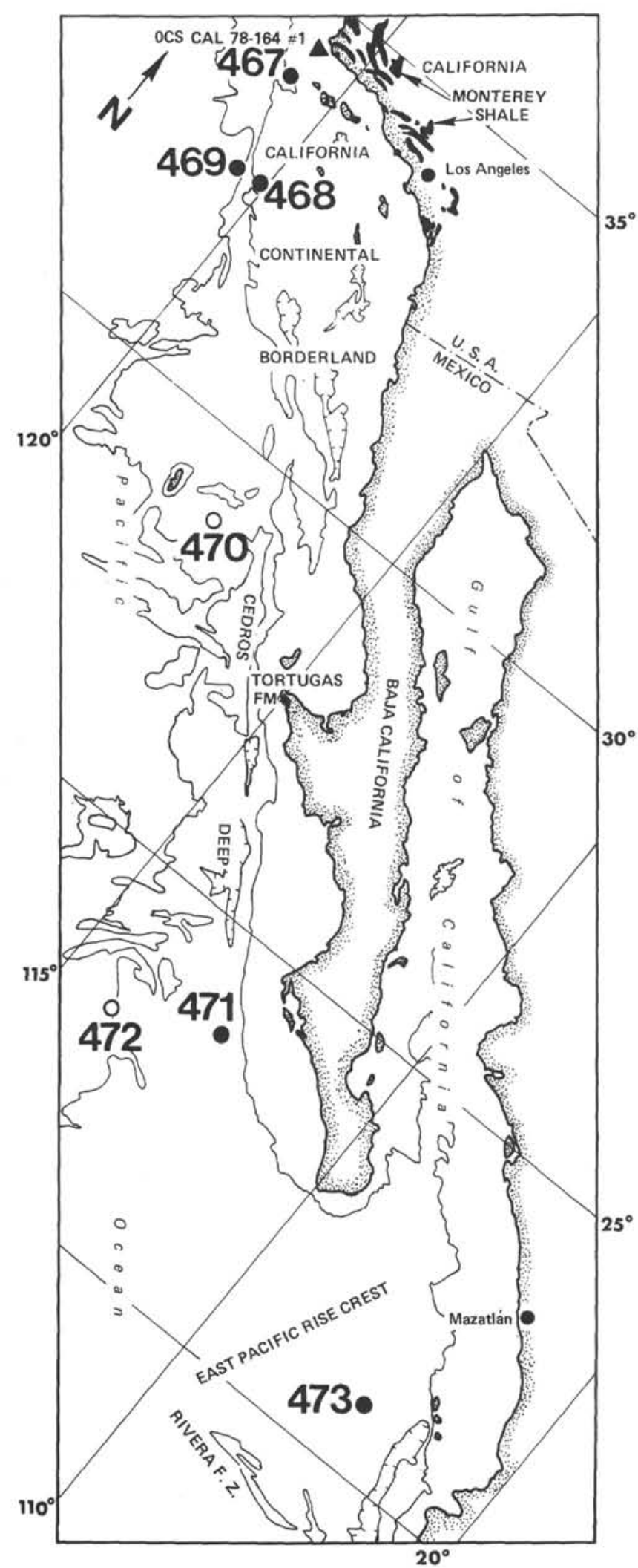

Figure 1. Location map of Leg 63 sites. (Filled symbols $=$ sites where authigenic silica was encountered; open symbols = no authigenic silica. Onshore outcrop areas of the siliceous facies of the Monterey Shale [California] and the Tortugas Formation [Baja California] are also shown.) porcellanite refers to a fine-grained siliceous sedimentary rock with a dull or matte luster resembling that of unglazed porcelain. Textural data presented in this paper come principally from the examination of slabbed cores and thin sections. We also examined the ultramorphology of selected specimens using scanning electron microscopy (SEM).

We determined bulk mineralogical compositions of the siliceous rocks of this study from routine X-ray diffraction scans at $2 \theta=$ $1 \%$ min using Ni-filtered $\mathrm{CuK} \alpha$ radiation. To obtain detailed measurements of the d(101)-spacing of opal-CT we scanned samples at $2 \theta=$ $1 / 2 \%$ min, averaging the forward and reverse runs for a single determination with quartz as the internal standard, as prescribed by Murata and Larson (1975).

Chemical compositions come from standard wet chemical techniques. The amounts of "soluble" and "insoluble" silica were determined using a chemical method based on the relative solubilities of silica minerals in acid and alkaline solutions (Zalmanzon, 1957). We use the term "soluble" silica for the total (summation) amount of $\mathrm{SiO}_{2}$ dissolved in successive two-fold treatments with $\mathrm{Na}_{2} \mathrm{CO}_{4}$, heating in a water bath for 2 hours each time. In addition to $\mathrm{SiO}_{2}, \mathrm{Al}_{2} \mathrm{O}_{3}$ and $\mathrm{Fe}_{2} \mathrm{O}_{3}$ were analyzed in the sodium extracts to monitor possible decomposition of aluminosilicates during the treatments. We use the term "insoluble" silica to designate the amount of $\mathrm{SiO}_{2}$ remaining after samples were decomposed for $15 \mathrm{~min}$ at $250^{\circ} \mathrm{C}$ to $280^{\circ} \mathrm{C}$ in phosphoric acid (specific gravity $=1.8 \mathrm{~g} / \mathrm{cm}^{3}$ ) and then soluble silica was removed with a $\mathrm{NaCO}_{3}$ solution. The insoluble residue is free silica, principally quartz; its purity was checked with hydrofluoric acid. The amounts of insoluble and soluble silica, when summed, equal the amount of free silica in the sample (i.e., silica not bound in aluminosilicates). All chemically analyzed samples were also examined with XRD and thin sections.

\section{RESULTS}

\section{Mineralogy and Texture}

The siliceous rocks recovered at Leg 63 sites represent a broad spectrum of mineralogies and textures from unaltered diatom ooze and diatomaceous silty clay to vitreous chert, spherulitic jasper, porcellanite, and weakly cemented, siliceous clayey chalk and calcareous claystone. Figure 2 summarizes the stratigraphy at each site. We consider the range of mineralogies and textures under the three general lithologic headings that follow.

\section{Diatomaceous Sediments}

These deposits represent the starting material from which porcellanites, siliceous mudrocks, and some of the cherts formed. These sediments vary from diatomaceous silty clay-containing variable amounts of diatoms, radiolarians, sponge spicules, calcareous nannofossils, authigenic carbonate, aluminosilicates, and detrital quartz and feldspar (Fig. 3, A)-to relatively pure diatom ooze (Fig. 3, B). Biogenic silica is opal-A in all cases. The age of most diatomaceous deposits at Leg 63 sites is late Miocene, although this varies somewhat (Fig. 2). These sediments are soft, and in most cores rotary drilling has destroyed original sedimentary structures. Burrows are common, however, in occasional authigenic carbonates occurring within these sediments (Pisciotto and Mahoney, this volume), suggesting that the diatomaceous sediments too are extensively burrowed. We observed no laminated deposits. At those sites where we detected authigenic silica, the shallowest occurrence of opal-CT generally coincides with a marked decrease in the preservation and abundance of siliceous microfossils (Fig. 4). 


\section{Porcellanites and Siliceous Mudrocks}

Porcellanites and siliceous mudrocks are the most common siliceous lithologies at Leg 63 sites. Opal-CT is the dominant silica mineral in such rocks, although subordinate authigenic quartz (chalcedony) is usually present as well. At Site 467 burrowed upper Miocene calcareous claystones are only weakly cemented with opal$\mathrm{CT}$ and do not have the vitreous or matte lusters characteristic of chert and porcellanite, respectively (Fig. 5, A and $\mathrm{B})$.

We recovered several fragments of porcellanite at Site 468. These rocks are burrow-mottled and contain more silica and less carbonate than the siliceous rocks at Site 467.

The siliceous rocks at Site 469 are principally middle Miocene calcareous porcellanite and siliceous clayey chalk (Fig. 5, C-E). Opal-CT, the dominant silica mineral, is a patchy cement between individual or groups of carbonate crystals; it also fills microfossil molds. In addition, a middle Miocene andesitic breccia recovered at this site contains angular fragments of volcanic rocks, pelecypod shells, and bryozoans and is cemented with opal-CT (Fig. 5, F-G). In contrast, a siliceous dolomite in Core 39 , immediately above the diabase sill, has a porcelaneous texture but the dominant silica mineral is quartz.

The thickest section of porcellanites encountered during Leg 63 occurs at Site 471 . These upper Miocene rocks are burrow-mottled, contain abundant opal-CT (Fig. 5, H-I), and are underlain by a thick section of middle Miocene silty claystone with abundant thin, sandy turbiditic layers. Although recovery was poor, caliper, sonic, and density logs indicate that the siliceous part of the section consists of thin intervals of alternating hard siliceous rocks-porcellanite and occasional opal-CT chert-and softer unaltered diatomaceous sediments (Fig. 6).

The siliceous rocks at Site 473 include upper Miocene porcellanite and porcelaneous silty claystone that are texturally similar to those recovered at Site 471 . Opal$\mathrm{CT}$ is the dominant silica mineral in these rocks.

\section{Cherts}

Cherts are much less abundant than porcellanites and siliceous mudrocks at Leg 63 sites. They occur in two modes: (1) as scattered nodules and thin layers within the sedimentary section and (2) as minor intercalations and fracture fillings in diabases and pillow basalts.

Chert nodules and thin layers occur within the sedimentary sections at Sites 467 and 471 . At Site 467 we recovered small fragments of black, vitreous opal-CT chert in Cores 71 and 77 at about 662 and 720 meters, respectively; these probably represent small nodules within calcareous and nannofossil claystone. Below this, in Cores 78, 79, and 92 (about 738 and $862 \mathrm{~m}$ ), small nodules of black quartzose chert occur (Fig. 7, A and B). Concentric banding in one specimen (Fig. 7, A) matches similar features described from the Monterey Shale, Franciscan chert, and Sierra Nevada Mesozoic cherts in California and in the Arkansas Novaculite (Taliaferro, 1934).

Several opal-CT cherts occur within the 150-meterthick section of opal-CT porcellanites at Site 471 . These cherts still retain many sedimentary structures, such as burrow mottling and thin lenticular bedding (Fig. 7, C). Opal-CT, the principal silica mineral, occurs as a cryptocrystalline cement (Fig. 7, D-E).

Reddish brown cherts occur at Site 469 within the basalt. In some cases these siliceous rocks fill fractures in the basalt; others are apparently minor intercalations within the basalt (Cores 44 and 45, about 396 and 407 $\mathrm{m}$, respectively). We found no ghosts or molds of siliceous microfossils in these rocks to support a biogenic origin. One sample, a spherulitic jasper, is texturally and mineralogically similar to jasper associated with pillow basalts in the Franciscan complex in California (e.g., compare Fig. 7, F and G).

At Site 471 a single fragment of black quartzose chert occurs between underlying altered diabase and diabase breccia and overlying chalcopyrite- and sphalerite-bearing rocks (Fig. 7, H). Microcrystalline quartz is the dominant silica mineral in this rock; we observed no radiolarian molds or other evidence of siliceous microfossils in thin section (Fig. 7, I).

\section{Chemistry}

Table 1 lists the chemical analyses of siliceous rocks and several clays recovered during Leg 63. Table 2 summarizes the measurements of soluble and insoluble silica in these samples. Diatom ooze and diatomaceous silty clay have the lowest silica contents of the siliceous sediments and rocks analyzed. The richest diatomaceous deposits, at Site 471 , contain $68 \%$ to $71 \%$ total silica and $50 \%$ to $55 \%$ free silica. Most of this free silica is opal-A, although detrital quartz occurs in all samples. $\mathrm{SiO}_{2} / \mathrm{Al}_{2} \mathrm{O}_{3}$ is about 12 to $15 .^{2}$ Opal-CT cherts, porcellanites, and siliceous mudrocks contain greater amounts of silica, up to $80 \%$ to $90 \%$; free silica, mostly opal-CT with minor quartz and opal-A, is greater than $60 \%$. $\mathrm{SiO}_{2} / \mathrm{Al}_{2} \mathrm{O}_{3}$ ranges from 15 to 60 . Higher silica contents characterize quartz cherts. Total $\mathrm{SiO}_{2}$ is over $90 \%$, almost all of which is free silica. About $30 \%$ of the free silica is soluble in sodium extracts, suggesting that some of the authigenic quartz is finely crystalline (e.g., Grechin, 1972; Fournier, 1973). $\mathrm{SiO}_{2} / \mathrm{Al}_{2} \mathrm{O}_{3}$ is about 200.

\section{Silica Mineral Zones}

Figure 2 summarizes the distribution of biogenic and authigenic silica at Leg 63 sites based on routine XRD analyses. Opal-A is present at all sites in the form of siliceous microfossils, principally diatoms but including radiolarians, sponge spicules, and silicoflagellates as well.

\footnotetext{
${ }^{2}$ For comparison, $\mathrm{SiO}_{2} / \mathrm{Al}_{2} \mathrm{O}$, in smectite is about 3. Rateev et al. (this volume) report that smectite is the main or the only aluminosilicate in the $<0.001-\mathrm{mm}$ fraction of Leg 63 samples containing no appreciable mixture of silt and sand. Thus $\mathrm{SiO}_{2} / \mathrm{Al}_{2} \mathrm{O},=3$ is an approximate value estimating the amount of silica bound in aluminosilicates (Khvorova, 1968). $\mathrm{SiO}_{2} / \mathrm{Al}_{2} \mathrm{O},>3$ may indicate an appreciable amount of free silica (i.e., opal-A, opal-CT, or quartz) in a sample.
} 
CALIFORNIA CONTINENTAL BORDERLAND
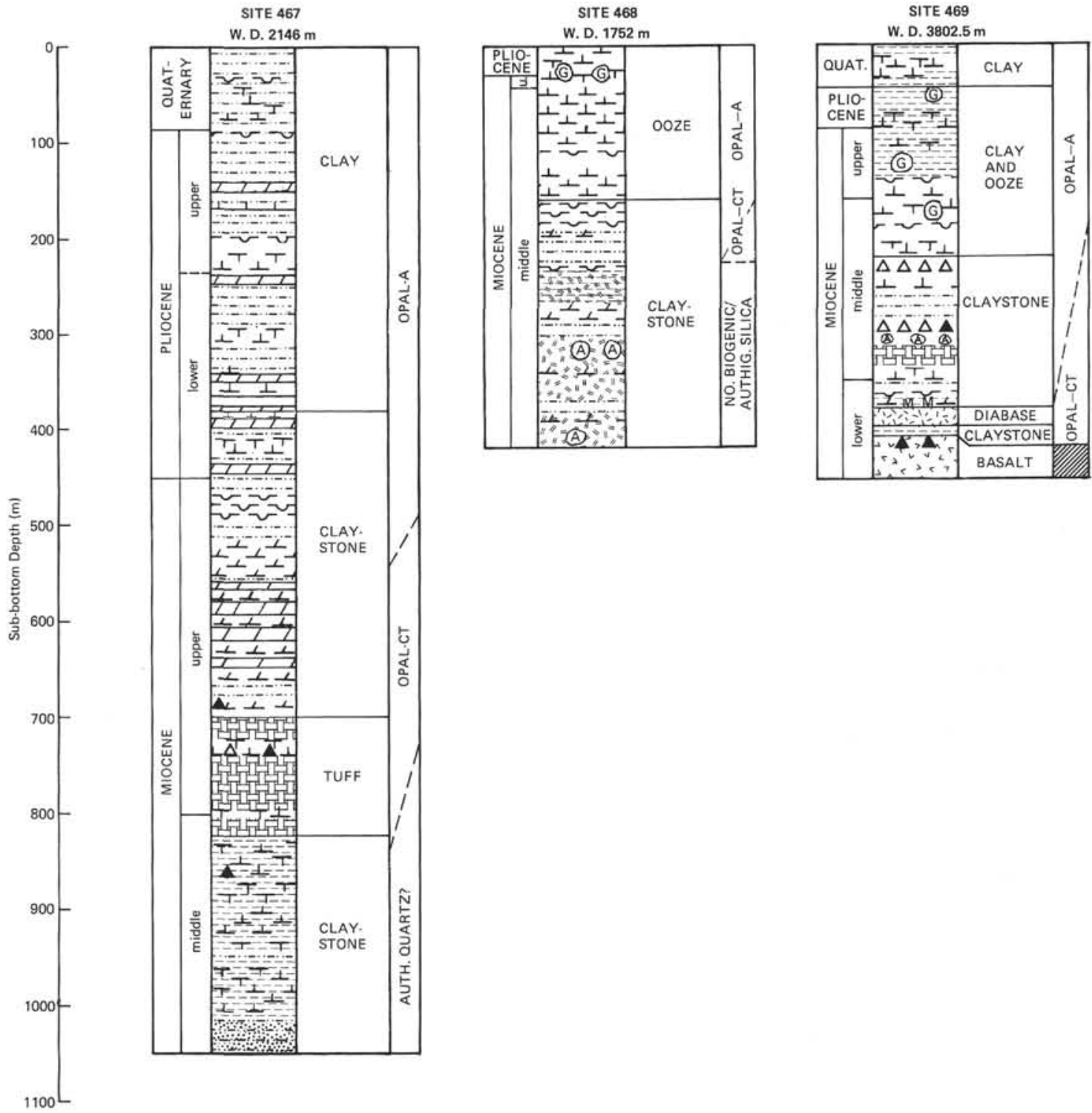

Figure 2. Lithologic and stratigraphic summary of Leg 63 sites showing distribution of silica minerals.

We detected opal-CT at five sites (Fig. 2). At Sites $468,469,471$, and 473 , opal-A persists to a depth of about 150 to 200 meters before converting to opal-CT through several tens of meters of section. At Site 467 the transition between opal-A and opal-CT occurs more deeply in the section, about 500 to 530 meters; opal-CT continues to at least 725 meters, where volcaniclastic rocks become abundant. At Site 471 the boundary between the opal-A and the opal-CT zones corresponds with a strong bottom-parallel seismic reflector that can be traced $80 \mathrm{~km}$ northwest along the western coast of Baja California (Fig. 8).

Within the opal-CT zone at Sites 467,469 , and 471 , the d(101)-spacing of opal-CT generally decreases from 4.10-4.12 $\AA$ to about $4.07-4.08 \AA$, although patterns are quite irregular in detail (Fig. 9). Four samples from Hole 473 spanning a depth interval of about 30 meters have d(101)-spacings that decrease from about $4.12 \AA$ to $4.09 \AA$. The $\mathrm{d}(101)$-spacing of the single sample from Hole 468 is about $4.10 \AA$.

At Site 467 we recovered isolated quartzose chert nodules in clayey chalk at depths of about 738 and 862 meters (Cores 78, 79, and 92). These scattered nodules may indicate the presence of a diagenetic quartz zone below the opal-CT zone at this site; the enclosing clayey chalk apparently contains minor authigenic (partly soluble) quartz (Sample 467-98-2, 44-46 cm; Tables 1, 2). Similarly, at Site 471 the occurrence of a minor authigenic (partly soluble) quartz in silty claystone below the opal-CT zone (Sample 471-35-3, 26-30; Tables 1, 2) suggests the presence of a diagenetic quartz zone. Authigenic quartz also occurs in the black chert near the base of this hole, but its association with altered igneous rocks and sulfide mineralization suggests that it is 
WESTERN CONTINENTAL MARGIN OF MEXICO

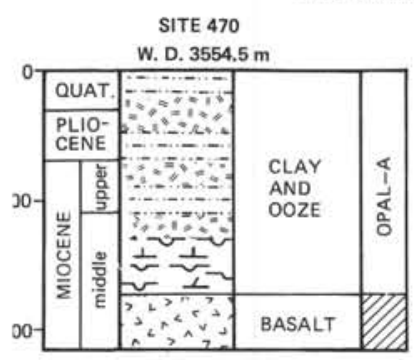

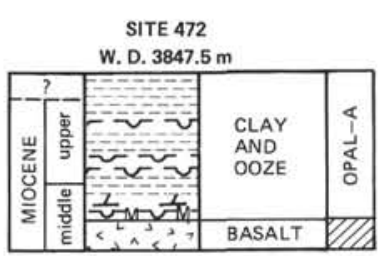
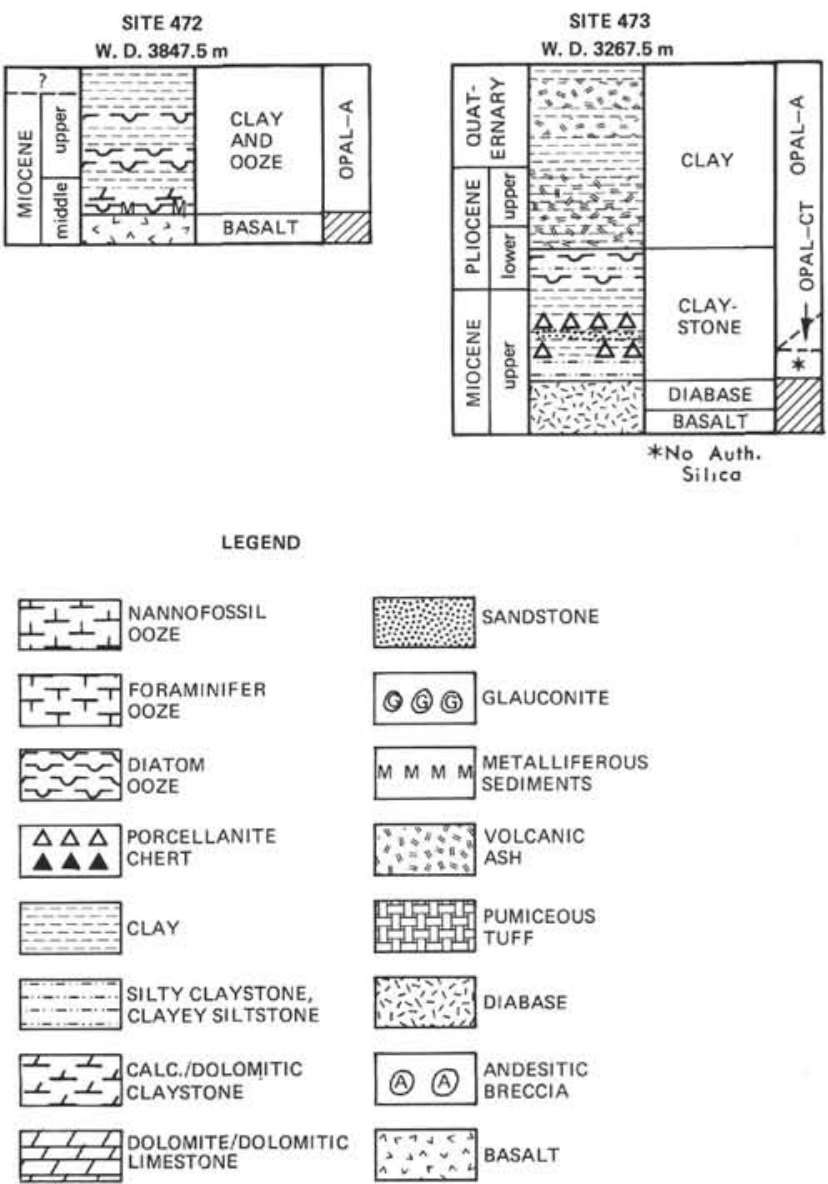

Figure 2. (Continued).

related to hydrothermal processes rather than burial heating. Authigenic quartz contained in chert, jasper, and siliceous dolomite associated with igneous rocks at Site 469 may have had a similar origin.

\section{DISCUSSION}

\section{Thermal Gradients and Silica Zones}

Experimental and field studies stress time and temperature (i.e., thermal history) as important factors controlling the rates of transformations of silica minerals (e.g., Mizutani, 1966, 1967, 1970; Ernst and Calvert, 1969; Murata and Larson, 1975). For diagenetically altered diatomaceous rocks around the Pacific margin, both the depth to the shallowest occurrence of opal-CT and the thickness of the opal-CT zone vary inversely with present thermal gradient; greater burial depths and thicker zones correspond to lower gradients (Pisciotto, 1978, 1979). Results listed in Table 3, compiled from our XRD results, heat-flow-probe measurements, and logging runs (see the physical properties sections of the site chapters in this volume), and from the recently drilled Point Conception Deep Stratigraphic Test Well OCS CAL 78-164 No. 1 (see Fig. 1 for location; Hein et al., 1979; McCulloh and Beyer, 1979), generally support this trend.

We have no gradient data for Sites 468 and 469 in the outer California Continental Borderland, but the shallow depth to the top of the opal-CT zone at each locality suggests gradients in the range of those at Sites 471, 472, and 473 off Baja California rather than the lower values prevailing at Site 467 and the Point Conception Well. At Site 468 we detected opal-CT only in the first hole drilled. Upper Miocene strata are not represented in this 

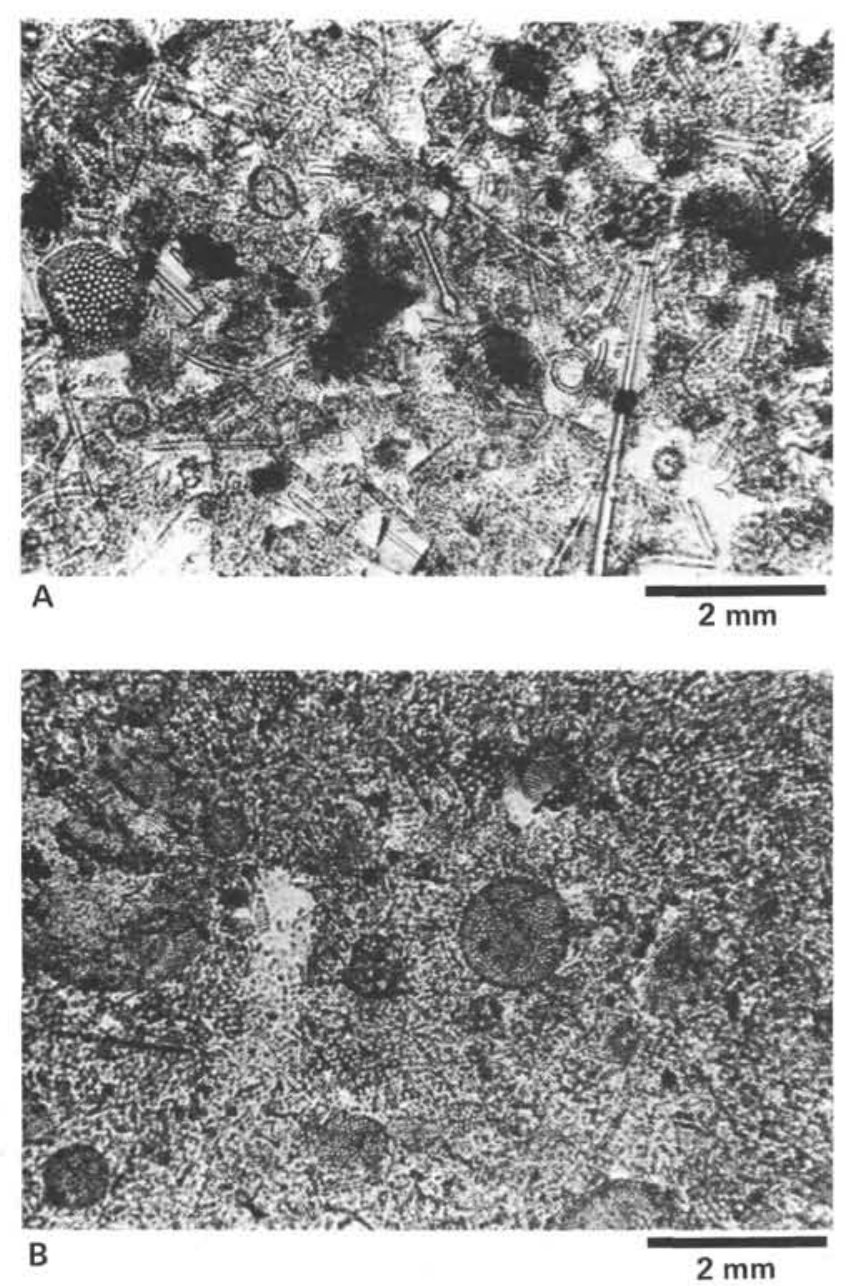

Figure 3. Typical textures and compositions of diatomaceous sediments recovered during Leg 63. A. Diatomaceous clay; smear slide, plane light (Sample 467-18-3, $30 \mathrm{~cm}$ ). B. Diatom ooze; smear slide, plane light (Sample 471-13-4, $106 \mathrm{~cm}$ ).

hole (see the Site 468 chapter) and it is possible that the middle Miocene siliceous rocks that now contain minor amounts of opal-CT were at one time more deeply buried. Thus the relatively shallow depth to the top of the opal-CT zone in this hole may reflect removal of overburden rather than a high thermal gradient. A similar situation at Site 469 is unlikely because no significant unconformities exist there.

Estimates of present subsurface temperatures at the opal-A-opal-CT transition are equivocal because of the uncertainties in measuring the thermal gradients. Using the data in Table 3 and present bottom-water temperatures at each locality (see the site chapters in this volume), the temperature range is $13^{\circ} \mathrm{C}$ to $52^{\circ} \mathrm{C}$ for the opal-A-opal-CT transition. This range is only a rough approximation of the temperatures of this silica transformation. At some sites, particularly Site 471, hydrothermal activity or emplacement of sills may have provided short-lived thermal pulses. If heat released from these events was conducted over appreciable vertical distances in the overlying sediments then silica transformations may have been affected.
Similarities with Circum-Pacific Siliceous Rocks

\section{Lithofacies}

Widespread middle and upper Miocene diatomaceous sediments and their diagenetic equivalentscherts, porcellanites, and siliceous mudrocks-occupy a common position in strikingly similar sequences of Neogene facies in the marginal Pacific. A common sequence begins with Oligocene to lower Miocene volcanic rocks, continental and/or neritic marine clastic rocks, followed by middle and upper Miocene diatomaceous sediments, sometimes with phosphatic basal parts, and often capped by Pliocene to Quaternary coarse clastic deposits and turbidites (Ingle, 1973; Garrison, 1976; Ingle et al., 1978). The lithologic sequences encountered at Leg 63 sites have some similarities with this generalized succession. For example, at Site 467 upper Miocene opal-CT-bearing calcareous claystone rests conformably on middle and upper Miocene pumiceous lapilli tuff. Pliocene and Quaternary silty claystone occurs above the calcareous claystone (Fig. 2). Similar lithologic sequences can be found on nearby Santa Cruz Island about $80 \mathrm{~km}$ east of this site (Weaver et al., 1969; Fisher and Charlton, 1976; McLean et al., 1976), across the Pacific on the Kamchatka Peninsula in the Soviet Far East (Grechin, 1971, 1976), and in Japan (Ingle, 1973; Garrison, 1976). The vertical successions of facies at Sites 468 and 469 are similar to the sequence at Site 467 , with the difference that Pliocene to Quaternary deposits are hemipelagic nannofossil ooze and clay rather than silty clay.

At Site 471 the succession of facies resembles coeval sequences in California (Bramlette, 1946; Ingle, 1973, in press), Baja California (Ingle, 1973; Minch et al., 1976; Helenes and Ingle, 1979), coastal Peru (Cheney et al., 1979), Sakhalin (Brodskaya and Iljinskaya, 1968), and Japan (Garrison, 1976, p. 62; and references therein). The siliceous facies at this site includes upper Miocene diatomaceous ooze and clay above porcellanites; below is a thick section of middle Miocene claystone punctuated frequently with sandy turbidites, some containing phosphate pellets. Above the siliceous facies is a thin interval of Pliocene to Quaternary nannofossil clay (Fig. 2). The analogous sequences in California (Monterey Shale), Baja California (Tortugas Formation), Peru (Sechura Desert sequence), Sakhalin (Pilskaya and Tumskaya Formations, and Japan (Nanao Group) also include phosphatic rocks associated with a distinct siliceous facies of chert, porcellanite, siliceous shale, and diatomite. The overlying Pliocene to Quaternary rocks in these areas, however, tend to be more coarsegrained than those at Site 471 .

Broad similarities exist between the lithologic sequences at Sites 470, 472, and 473 and lithofacies encountered in the southern Bering Sea and far northwest Pacific (Hein et al., 1978) and in the Southern Ocean (Hayes et al., 1975; Hollister et al., 1976; Brewster, 1980). At Site 473 upper Miocene opal-CT porcellanite and claystone occur below diatomaceous sediments and ash-rich clay as in the Bering Sea. The sequence is similar at Site 470 , except that diagenetically altered 

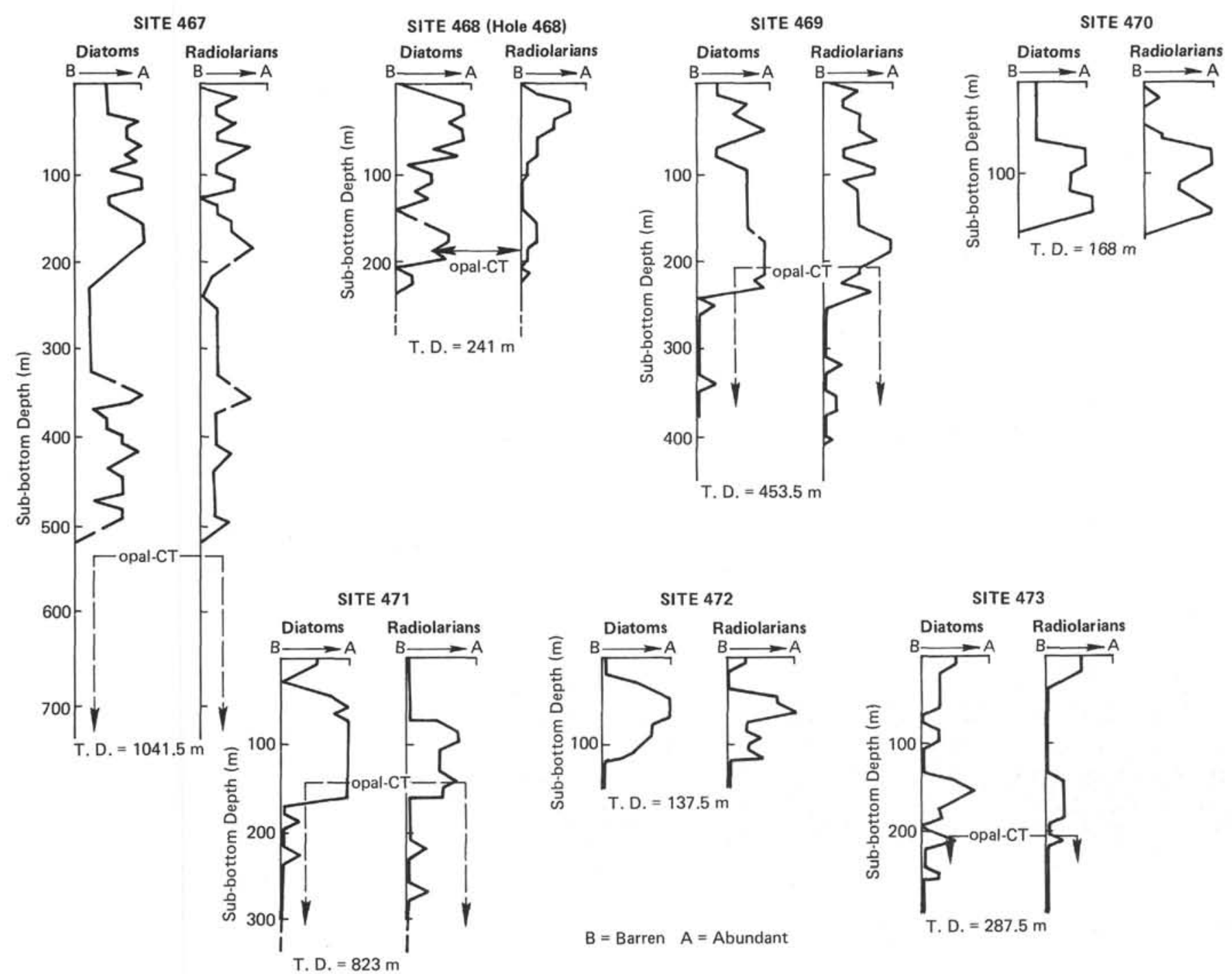

Figure 4. Abundance plots of siliceous microfossils (opal-A) and occurrences of opal-CT at Leg 63 sites.

siliceous rocks are absent. Site 472 is unique in that middle and upper Miocene diatomaceous sediments at this locality pass upward to a condensed section of upper Miocene through Quaternary unfossiliferous reddish brown clay, in marked contrast with the coarse clastic facies that typically occurs in this position of the sequence. This unusual facies variation reflects the movement of this site away from both terrigenous sources and from areas of prolific diatom productivity during the late Miocene.

The cherts associated with basaltic rocks at Site 469 and 471 more closely resemble the Mesozoic cherts intercalated with igneous rocks in the Franciscan Complex in California (Davis, 1918; Bailey et al., 1964) and similar cherts and jaspers in the northwestern Cordillera (Park, 1942, 1946; Danner, 1970) than cherts in Neogene diatomaceous sequences in the circum-Pacific region. At Site 469, contacts between altered pillow basalts and reddish brown chert and jasper suggest that the siliceous rocks probably represent small restricted bodies of siliceous sediment originally deposited on and between and intruded by pillow lavas. They may have formed in a manner similar to inter- and intrapillow limestones (Garrison, 1972, 1974). The origin of the black chert at Site 471 is somewhat more equivocal, because drilling has destroyed original contacts. This specimen occurs above altered diabase and diabase breccia and below several centimeters of mineralized sediments (Fig. 7, H); it may represent thermally altered siliceous sediment deposited near active hydrothermal vents on the seafloor.

\section{Diagenesis}

Many diagenetic aspects of the siliceous rocks at Leg 63 sites are similar to those in coeval circum-Pacific sequences. The depth and temperature-related progression of silica minerals and lithologies and, less commonly, the shift in d(101)-spacing of opal-CT to lower values with increasing diagenesis are trends noted at selected localities in Japan (Mitsui and Taguchi, 1977; Iijima and Tada, in press), Kamchatka and Sakhalin (Grechin, 1976), the southern Bering Sea (Hein et al., 

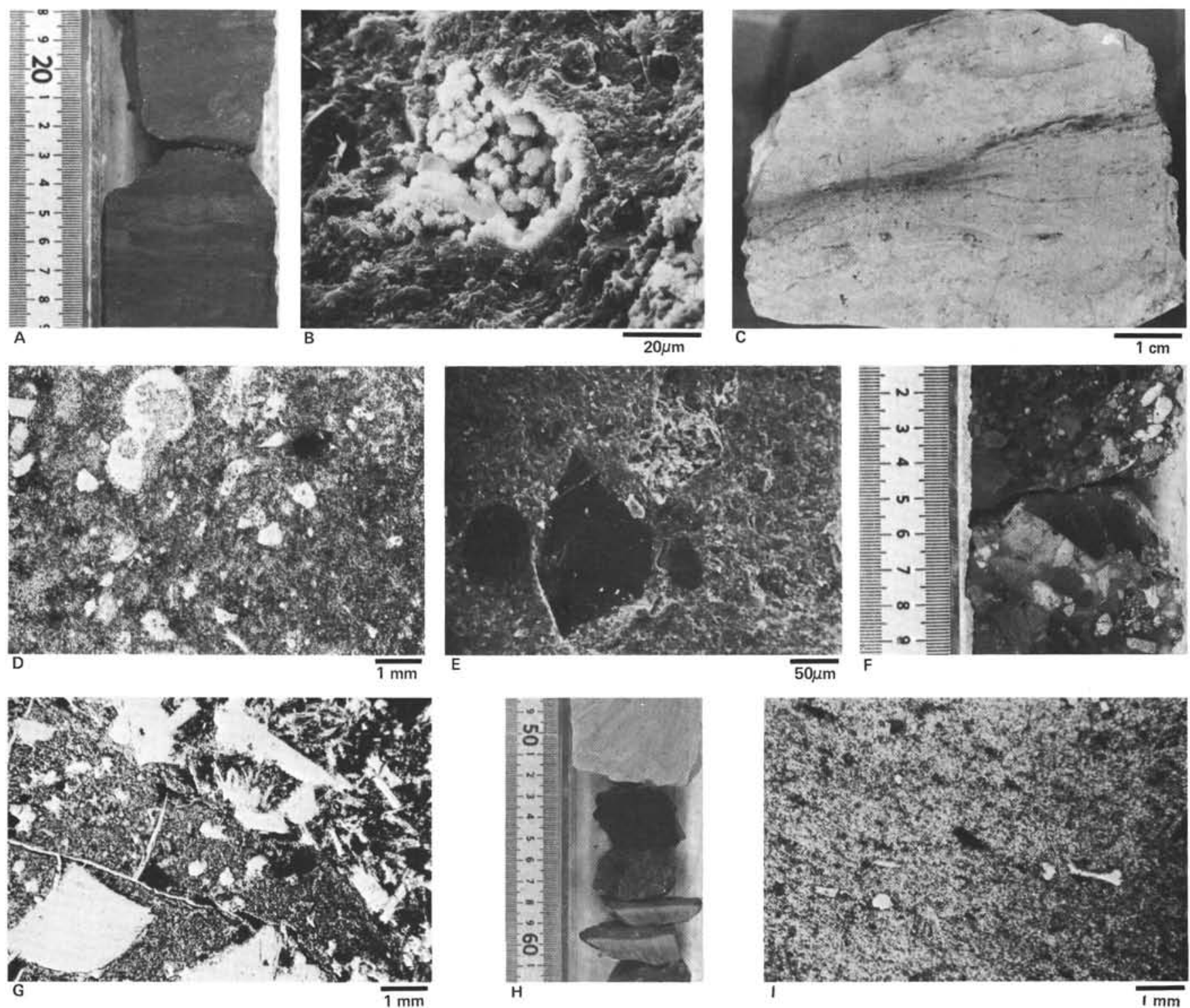

Figure 5. Textures of Leg 63 porcellanites and siliceous mudrocks. A. Core photo of burrowed, weakly silicified (opal-CT), calcareous claystone at Site 467 (Sample 467-69-2). B. SEM micrograph of A., showing well-formed opal-CT lepispheres in void. C. Core photo of calcareous porcellanite (opal-CT) at Site 469 (Sample 469-26,CC). D. Thin section photomicrograph of C., showing scattered calcareous microfossils, detrital grains, and small calcite crystals. (Cryptocrystalline opal-CT resides in the groundmass. Plane light.) E. SEM of C., showing angular detrital grains and round calcite-filled and replaced microfossils set in a cryptocrystalline groundmass of calcite and opal-CT. F. Core photo of opal-CT cemented volcaniclastic breccia at Site 469 (Sample 469-33-1; meter stick for scale). G. Thin-section photomicrograph of F., showing volcanic clasts and detrital grains that are cemented with opal-CT. (Plane light.) H. Core photo of burrowed porcellanite (opal-CT) at Site 471. (Porcellanite fragments are seen between 53 and $62 \mathrm{~cm}$ on the meter stick scale; dolomite occurs above [Sample 471-20-1].) I. Thin section photomicrograph of H., showing chalcedony-filled, bow-tie-shaped diatom molds set in a cryptocrystalline groundmass of opal-CT and clay. (Plane light.)

1978), California (Bramlette, 1946; Murata and Larson, 1975; Pisciotto, 1978; Isaacs, 1979), Baja California (Ingle, 1973, Minch et al., 1976; Helenes and Ingle, 1979) and in the Southern Ocean (Kastner, 1976). At Site 471 the bottom-parallel reflector corresponding to the transformation of diatomaceous sediments (opal-A) to hard opal-CT porcellanite and siliceous mudrocks compares directly with the bottom-simulating reflector in the southern Bering Sea (Scholl and Creager, 1973; Hein et al. 1978).

Aside from the transformations of silica, additional comparisons can be drawn between the diagenesis of
Leg 63 siliceous sequences and some coeval circumPacific Neogene siliceous deposits. For example, alteration of volcanic glass in ash and tuff to smectite, clinoptilolite, analcime, and, in some cases, $\mathrm{K}$-feldspar is common at all localities except Sites 470 and 472 (Fig. 10). Similar depth-related progressions of authigenic minerals occur in interbedded volcaniclastic rocks and associated siliceous sediments in Japan (e.g., Iijima and Utada, 1966; Iijima et al., in press; Iijima and Tada, in press) and in the Soviet Far East (Grechin, 1971, 1976). In addition, dolomites at Leg 63 sites (Fig. 10; Pisciotto and Mahoney, this volume) are compositionally and iso- 


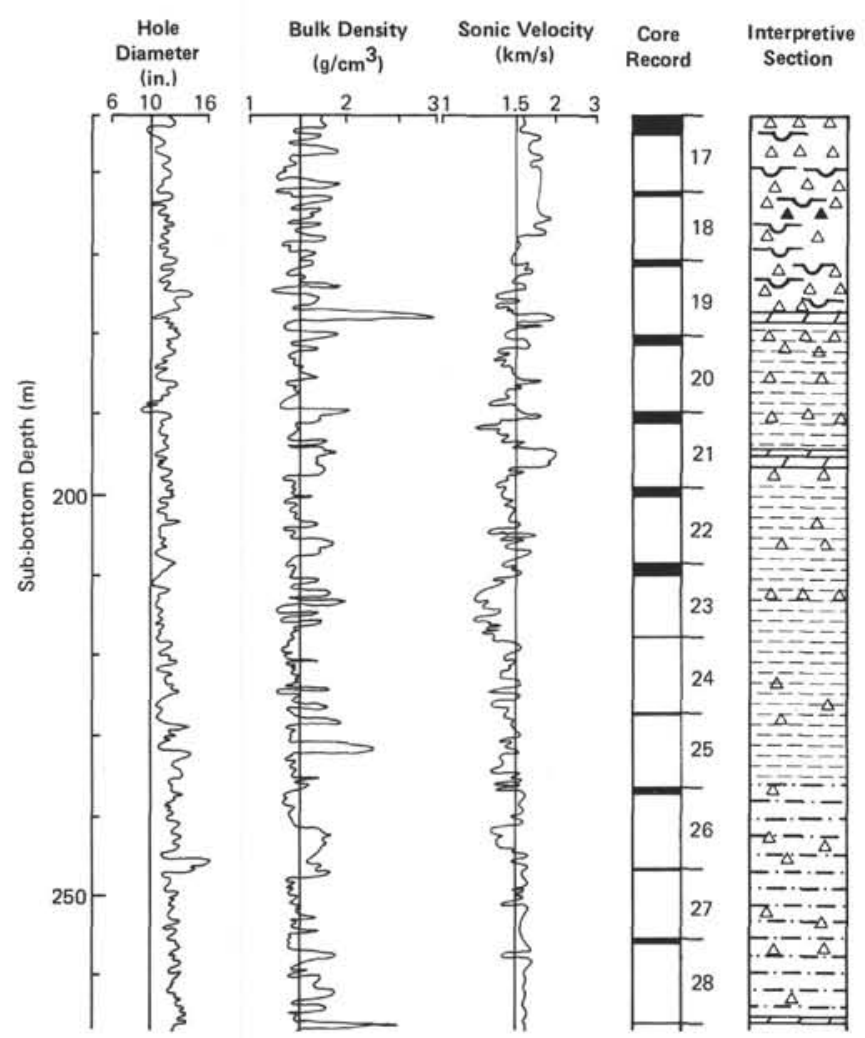

Figure 6. Density, velocity, and caliper logs of a poorly recovered porcelaneous interval at Site 471, showing probable distribution of diagenetically altered and unaltered siliceous rocks and associated dolomites. (See Fig. 2 for a key to the lithologic symbols. Core record column shows core numbers and recovered amounts [black areas].)

topically similar to concretionary dolomites and authigenic carbonates in diatomaceous and siliceous sequences in California (Murata et al., 1969, 1972; Friedman and Murata, 1979), Japan (Watanabe, 1970; Sawamura and Uemura, 1973) and the southern Bering Sea (Hein et al., 1979). The coincidence of many of these diagenetic changes in the subsurface suggests that common physical and chemical controls are involved.

\section{CONCLUSIONS}

1. At five of seven DSDP sites drilled off Southern California and Baja California, Neogene diatomaceous sediments are underlain by chert, porcellanite, and siliceous mudrock.

2. This major lithologic transition generally corresponds to the mineralogic transformation of opal-A to opal-CT. At Site 471 off Baja California this zonal boundary coincides with a bottom-parallel seismic reflector that is continuous for at least $80 \mathrm{~km}$ to the northwest.

3. At Sites 467,469 , and 471 the d(101)-spacing of opal-CT decreases from about $4.10-4.12 \AA$ to about $4.07 \AA$ with increasing depth of burial.

4. Significant amounts of partly soluble quartz in sedimentary rocks below the opal-CT zones at Sites 467 and 471 suggest the presence of diagenetic quartz zones at these localities.
5. The approximate range in present subsurface temperatures at the opal-A-opal-CT transition at Leg 63 sites is $13^{\circ} \mathrm{C}$ to $52^{\circ} \mathrm{C}$.

6 . High present thermal gradients generally correspond to shallow opal-CT zones.

7. The vertical sequences of facies encountered at Leg 63 DSDP sites are lithologically and diagenetically similar to some coeval sequences around the Pacific margin. At outer California Continental Borderland Sites 467, 468, and 469, upper Miocene siliceous rocks occur above lapilli tuff and volcanic breccia and below nannofossil ooze and silty clay. Similar sequences occur on Santa Cruz Island off California and in Japan and Kamchatka. At Site 471 off Baja California the vertical sequence of facies includes phosphate-bearing turbidites overlain by siliceous rocks, in turn overlain by nannofossil clay; this sequence resembles successions in California, Baja California, Peru, Japan, and Sakhalin. Diagenetic similarities between the Leg 63 rocks and coeval circum-Pacific sequences include the depth- and temperature-related transformation of biogenic silica (opal-A) to opal-CT and quartz, the alteration of volcanic glass to smectite, clinoptilolite, analcime, and $\mathrm{K}$-feldspar, and the occurrence of authigenic carbonates.

8. Quartz chert and spherulitic jasper intercalated with diabase and pillow basalt at Sites 469 and 471 probably represent small accumulations of thermally altered siliceous sediments deposited on active volcanic crust.

\section{ACKNOWLEDGMENTS}

We thank R. V. Rychkova of the Geological Institute of the U.S.S.R. Academy of Sciences for some of the chemical analyses presented in this paper. We also thank Tom Hilliard for preparation of the illustrations and Lola Boyce for typing the manuscript. R. E. Garrison and C. M. Isaacs reviewed the manuscript, and we appreciate their helpful suggestions. K. A. Pisciotto and J. J. Mahoney gratefully acknowledge financial support for this study from Chevron Oil Research and from the Geological Research Division at Scripps. Finally, we wish to thank the Leg 63 scientific staff and the crew of the Glomar Challenger for their counsel and technical assistance and the National Science Foundation, which funds the Deep Sea Drilling Project.

\section{REFERENCES}

Bailey, E. H., Irwin, W. P., and Jones, D. L., 1964. Franciscan and related rocks, and their significance in the geology of western California. Bull. Calif. Div. Mines Geol., 183.

Bramlette, M. N., 1946. The Monterey Formation of California and the origin of its siliceous rocks. U.S. Geol. Surv. Prof. Pap. 212.

Brewster, N. A., 1980. Cenozoic biogenic silica sedimentation in the Antarctic Ocean. Bull. Geol. Soc. Am., Pt. I, 91:337-347.

Brodskaya, N. G., and Iljinskaya, M. N., 1968. Phosphate accumulation in volcanic regions. Sedimentation and Ore Deposits of the Ancient Volcanic Regions: Tr. Inst. Geol. Akad. Nauk SSSR, 2 (196):193-292.

Cheney, T. M., McClellan, G. H., and Montgomery, E. S., 1979. Sechura phosphate deposits, their stratigraphy, origin and composition. Econ. Geol., 74:232-259.

Danner, W. R., 1970. Cherts and jaspers of the western Cordilleran eugeosyncline of southwestern British Columbia and northwestern Washington. Tr. Min. Geol. Metall. Inst. India, West Commemoration Volume, pp. 533-553.

Davis, E. F., 1918. The radiolarian cherts of the Franciscan group. Univ. Calif. Publ. Geol. Sci., 11:235-432.

Ernst, W. G., and Calvert, S. E., 1969. An experimental study of the recrystallization of porcellanite and its bearing on the origin of some bedded cherts. Am. J. Sci., 267-A:114-133. 

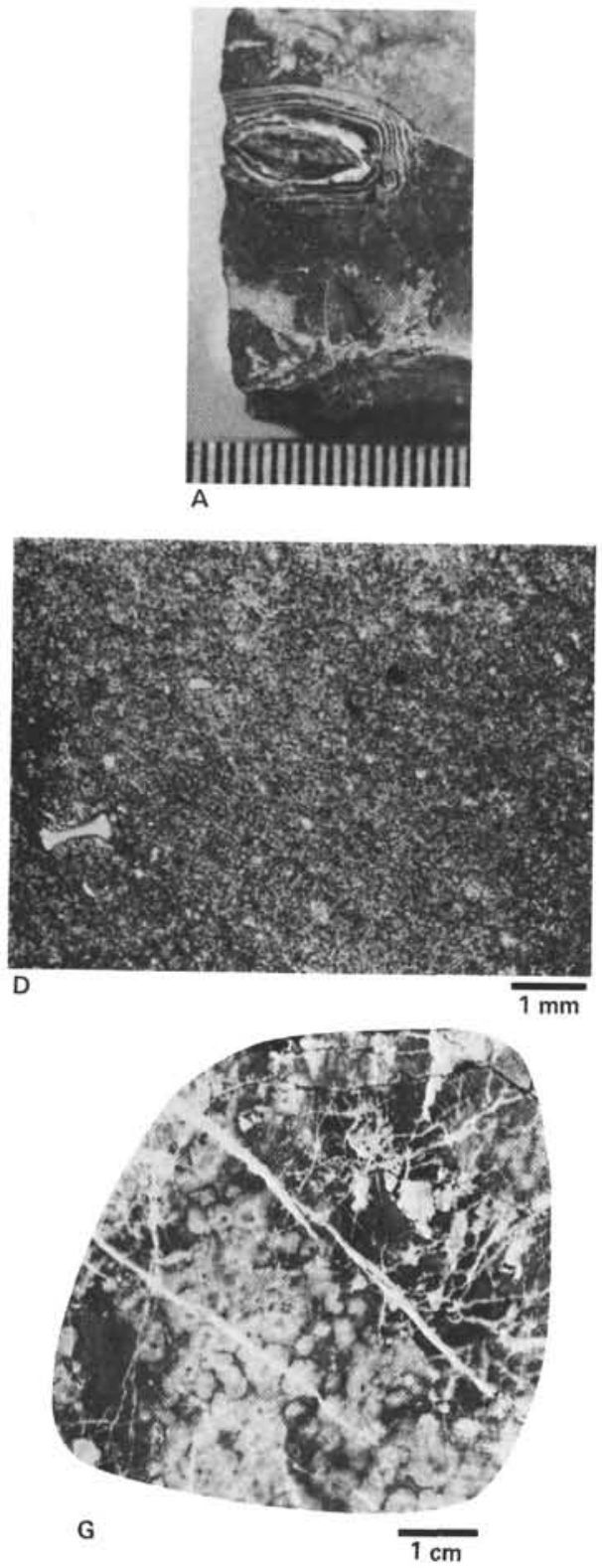

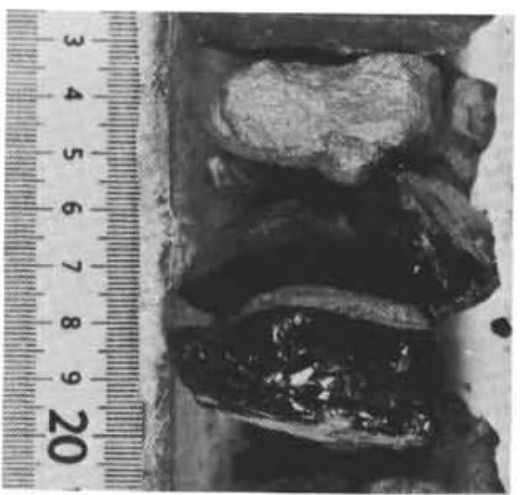

B
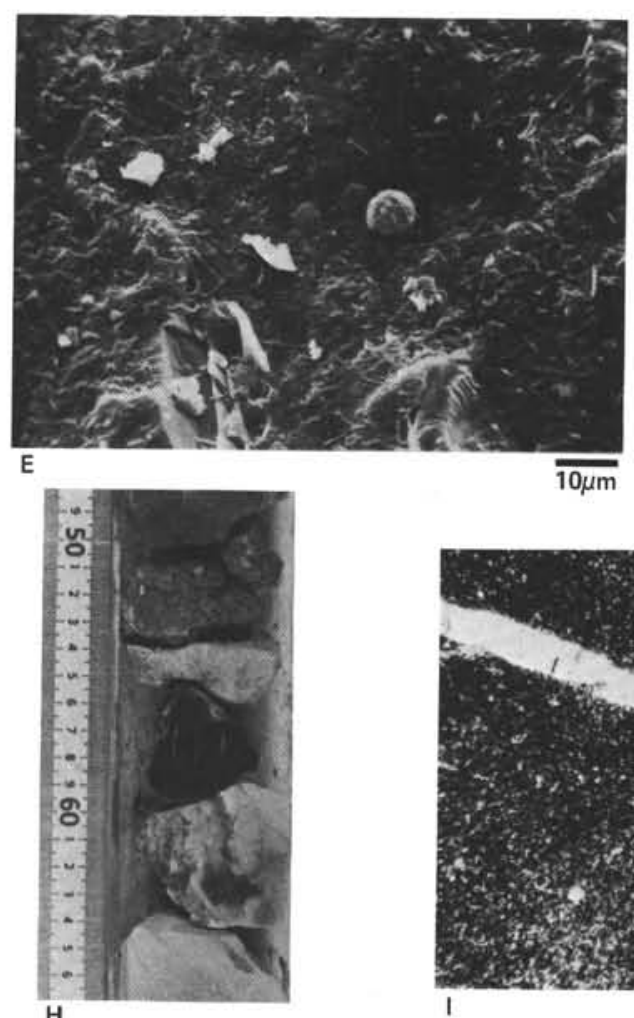

$\mathrm{H}$

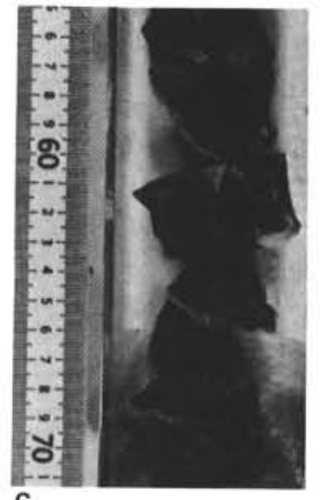

C
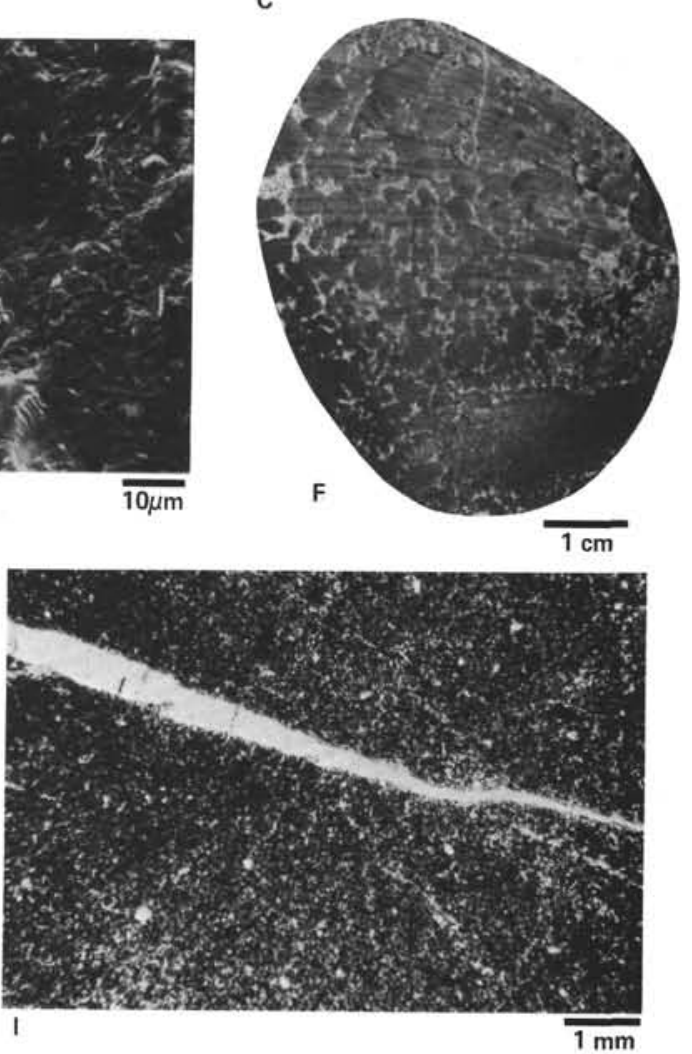

Figure 7. Textures of Leg 63 cherts. A. Core photo of concentrically banded chert nodule in silicified calcareous claystone at Site 467 (Sample $467-$ 92-1). (For similar nodules in the Monterey Shale [California], the light bands are opal-CT, dark are quartz [Pisciotto, 1978]. Scale is in millimeters.) B. Core photo of quartzose chert nodule in silicified calcareous claystone at Site 467 (Sample 467-92-1). The meter stick is used for a scale.) C. Core photo of fractured (drilling artifact) opal-CT chert at Site 471 (Sample 471-18,CC). (Meter stick for scale.) D. Thin-section photomicrograph of C., showing chalcedony-filled bow-tie-shaped diatom mold set in groundmass of opal-CT and clay.) E. SEM photo of C., showing pyrite framboids on fractured surface of opal-CT cemented clay. (Thin bands on the surface may be fracture filling of opal-CT exposed during preparation of sample. F. Hand specimen of spherulitic jasper (quartz) at Site 469 (Sample 469-45-3). G. Hand specimen of spherulitic jasper (quartz) from pillow basalts of the Mesozoic Franciscan Complex, Kirby Cove near San Francisco, California. H. Core photo of black quartzose chert associated with sulfide mineralization at Site 471 (Sample 471-79-1). (Meter stick for scale. Sediments from 48-55 cm bear chalcopyrite and sphalerite; chert is found from $55-60 \mathrm{~cm}$; and altered basalt from $60-67 \mathrm{~cm}$. The white veins in chert are calcite.) I. Thinsection photomicrographs of $\mathrm{H}$., showing cryptocrystalline quartz cut by calcite vein. (Note the lack of microfossils. Crossed nichols.) 
Table 1. Chemical compositions of siliceous rocks and several clays recovered during Leg 63.

\begin{tabular}{|c|c|c|c|c|c|c|c|c|c|c|c|c|c|c|c|c|c|c|c|c|c|c|c|c|c|c|}
\hline $\begin{array}{c}\begin{array}{c}\text { Sample } \\
\text { (interval in } \mathrm{cm} \text { ) }\end{array} \\
\text {. }\end{array}$ & $\begin{array}{c}\text { Sub-bottom } \\
\text { Depth } \\
\text { (m) }\end{array}$ & Lithology $^{\mathrm{a}}$ & $\mathrm{SiO}_{2}$ & $\mathrm{TiO}_{2}$ & $\mathrm{Al}_{2} \mathrm{O}_{3}$ & $\begin{array}{c}\text { Total } \\
\text { Iron }\end{array}$ & $\mathrm{FeO}$ & $\mathrm{Fe}_{2} \mathrm{O}_{3} \mathrm{~b}$ & $\mathrm{MnO}$ & $\mathrm{MgO}$ & $\mathrm{CaO}$ & $\mathrm{Na}_{2} \mathrm{O}$ & $\mathrm{K}_{2} \mathrm{O}$ & $\mathrm{H}_{2} \mathrm{O}^{+}$ & $\mathrm{H}_{2} \mathrm{O}^{-}$ & $\mathrm{P}_{2} \mathrm{O}_{5}$ & $\mathrm{CO}_{2}$ & c & $\mathrm{SO}_{3}$ & $\mathrm{Cl}$ & s & LOI $^{\mathrm{C}}$ & Total & $0=$ & $\mathrm{O}=\mathrm{Cl}^{\mathrm{d}}$ & Total \\
\hline \multicolumn{27}{|l|}{ Site 467} \\
\hline 19-5, $115-120$ & 174.6 & Diatom calc, clay (A) & 45.32 & 0.42 & 5.12 & 5.47 & 0.58 & 4.89 & 0.01 & 1.10 & 15.61 & 2.87 & 1.27 & 3.14 & 2.74 & 0.21 & 10.05 & 4.10 & 0.80 & 1.67 & $-e$ & - & 99.90 & - & 0.37 & 99.53 \\
\hline $40-3,12-16$ & 370.1 & Diatom calc. clay (A) & 49.08 & 0.52 & 10.31 & 5.56 & 1.36 & 4.20 & 0.03 & 1.96 & 8.87 & 2.58 & 1.75 & 3.10 & 2.62 & 0.23 & 6.05 & 3.21 & 1.07 & 1.08 & 0.77 & 2.16 & 101.95 & 0.39 & 0.25 & 100.31 \\
\hline $69-1,130-134$ & 643.8 & Siliceous calc. clayst. (C) & 54.82 & 0.42 & 6.48 & 4.49 & 0.70 & 3.79 & 0.02 & 1.25 & 7.12 & 1.97 & 1.11 & 3.42 & 2.22 & 0.45 & 4.20 & 7.72 & 1.32 & 0.67 & 0.78 & 1.83 & 100.29 & 0.39 & 0.15 & 99.75 \\
\hline $78-1,61-62$ & 728.6 & Chert (Q) & 91.71 & 0.17 & 0.42 & 2.85 & 0.41 & 2.44 & $\overline{0}$ & 0.25 & 1.06 & 0.39 & 0.18 & 1.58 & 0.42 & 0.07 & 0.0 & 0.98 & - & - & - & - & 100.08 & - & -100.08 & \\
\hline & $\begin{array}{l}737.8 \\
862.2\end{array}$ & Chert (Q) & 95.67 & 0.17 & 0.56 & 1.27 & 0.15 & 1.12 & $\begin{array}{l}0.0 \\
0.0\end{array}$ & 0.34 & 0.35 & 0.29 & 0.12 & 0.79 & $\begin{array}{l}0.33 \\
0.37\end{array}$ & 0.03 & $\begin{array}{l}0.0 \\
0.75\end{array}$ & 0.19 & $\overline{0.38}$ & $\overline{0}$ & $\bar{z}$ & $\bar{z}$ & $\begin{array}{l}100.11 \\
99.93\end{array}$ & - & - & 100.11 \\
\hline $\begin{array}{l}92-1,116-118 \\
98-2,44-46\end{array}$ & $\begin{array}{l}862.2 \\
919.9\end{array}$ & $\begin{array}{l}\text { Chert (Q) } \\
\text { Siliceous chalk (Q) }\end{array}$ & $\begin{array}{l}91.74 \\
34.93\end{array}$ & $\begin{array}{l}0.17 \\
0.33\end{array}$ & $\begin{array}{l}0.53 \\
5.54\end{array}$ & $\begin{array}{l}1.32 \\
2.65\end{array}$ & $\begin{array}{l}0.10 \\
0.73\end{array}$ & $\begin{array}{l}1.22 \\
1.92\end{array}$ & $\begin{array}{l}0.0 \\
0.02\end{array}$ & $\begin{array}{l}0.60 \\
1.52\end{array}$ & $\begin{array}{l}1.98 \\
25.57\end{array}$ & $\begin{array}{l}0.29 \\
1.47\end{array}$ & $\begin{array}{l}0.18 \\
0.94\end{array}$ & $\begin{array}{l}1.25 \\
1.64\end{array}$ & $\begin{array}{l}0.37 \\
1.36\end{array}$ & $\begin{array}{l}0.07 \\
0.26\end{array}$ & $\begin{array}{l}0.75 \\
20.35\end{array}$ & $\begin{array}{l}0.30 \\
2.04\end{array}$ & $\begin{array}{l}0.38 \\
0.46\end{array}$ & $\begin{array}{l}0.0 \\
0.31\end{array}$ & $0 . \overline{74}$ & $=$ & $\begin{array}{r}99.93 \\
100.13\end{array}$ & $\overline{0.37}$ & $\overline{0.07}$ & $\begin{array}{l}99.93 \\
99969\end{array}$ \\
\hline \multicolumn{27}{|l|}{ Site 469} \\
\hline $24-3,6-10$ & 219.5 & Clayey diatom ooze (A) & 57.63 & 0.50 & 10.85 & 6.25 & 0.85 & 5.40 & 0.11 & 3.02 & 3.19 & 3.96 & 2.87 & 4.71 & 2.36 & 0.25 & 1.50 & 0.0 & 0.87 & 1.74 & 0.85 & - & 100.66 & 0.42 & 0.40 & 99.84 \\
\hline $36-1,62-66$ & 331.1 & Porcellanite (C) & 73.33 & 0.33 & 6.40 & 4.63 & 0.71 & 3.92 & 1.03 & 1.85 & 1.29 & 1.60 & 1.75 & 2.65 & 2.50 & 0.15 & 1.10 & 0.05 & 0.99 & 0.47 & 0.16 & - & 100.28 & 0.08 & 0.11 & 100.09 \\
\hline \multicolumn{27}{|l|}{ Site 470} \\
\hline $11-4,110-115$ & 100.1 & Clayey diatom ooze (A) & 59.34 & 0.52 & 9.25 & 5.71 & 0.89 & 4.82 & 0.10 & 3.09 & 3.66 & 3.82 & 2.44 & 3.97 & 3.38 & 0.16 & 1.85 & 0.33 & 1.02 & 2.28 & - & - & 100.92 & - & 0.52 & 100.40 \\
\hline \multicolumn{27}{|l|}{ Site 471} \\
\hline 10-5, $120-125$ & 92.7 & Diatom ooze (A) & 68.37 & 0.32 & 5.64 & 3.87 & 0.49 & 3.38 & 0.02 & 1.78 & 1.28 & 3.82 & 1.27 & 4.06 & 4.01 & 0.26 & 0.0 & 0.89 & 1.25 & 3.16 & 0.45 & - & 100.45 & 0.22 & 0.72 & 99.51 \\
\hline $17-2,120-125$ & 154.7 & Diatom ooze (A) & 71.00 & 0.25 & 4.86 & 2.10 & 0.61 & 1.49 & 0.02 & 1.56 & 1.15 & 3.54 & 1.05 & 5.50 & 3.40 & 0.20 & 0.0 & 0.71 & 1.25 & 3.30 & 0.67 & - & 100.56 & 0.33 & 0.75 & 99.48 \\
\hline $18, \mathrm{CC}, 16-20$ & 171.0 & $\begin{array}{l}\text { Chert }(C) \\
\text { Pore }\end{array}$ & 87.96 & 0.14 & 2.77 & 2.03 & 0.40 & 1.63 & 0.02 & 0.51 & 0.73 & 0.58 & 0.49 & 2.10 & 2.12 & 0.11 & 0.0 & 0.0 & 0.23 & 0.11 & $\overline{0}$ & - & $\begin{array}{r}99.90 \\
0.68\end{array}$ & $\overline{0.0}$ & 0.03 & 99.87 \\
\hline $19, \mathrm{CC}, 13-17$ & 180.5 & $\begin{array}{l}\text { Porcellanite (C) } \\
\text { Porcellanite (C) }\end{array}$ & $\begin{array}{l}89.77 \\
76.75\end{array}$ & $\begin{array}{l}0.09 \\
0.37\end{array}$ & $\begin{array}{l}1.50 \\
6.46\end{array}$ & $\begin{array}{l}1.56 \\
3.77\end{array}$ & $\begin{array}{l}0.26 \\
0.72\end{array}$ & $\begin{array}{l}1.30 \\
3.05\end{array}$ & $\begin{array}{l}0.01 \\
0.03\end{array}$ & & $\begin{array}{l}0.43 \\
0.84\end{array}$ & $\begin{array}{l}0.48 \\
1.60\end{array}$ & 0.31 & & $\begin{array}{l}1.93 \\
2.43\end{array}$ & 0.06 & $\begin{array}{l}0.0 \\
0.0\end{array}$ & $\begin{array}{l}0.55 \\
0.64\end{array}$ & 0.64 & 0.16 & $\begin{array}{l}0.24 \\
0.94\end{array}$ & $=$ & $\begin{array}{r}99.68 \\
100.25\end{array}$ & $\begin{array}{l}0.12 \\
0.47\end{array}$ & 0.04 & 99.52 \\
\hline $\begin{array}{l}23-1,0-5 \\
28, C C, 29-31\end{array}$ & $\begin{array}{l}269.0 \\
266.0\end{array}$ & $\begin{array}{l}\text { Porcellanitit (C) } \\
\text { Porcellanite (C) }\end{array}$ & $\begin{array}{l}76.75 \\
80.13\end{array}$ & $\begin{array}{l}0.37 \\
0.33\end{array}$ & $\begin{array}{l}6.46 \\
5.77\end{array}$ & $\begin{array}{l}3.77 \\
2.68\end{array}$ & $\begin{array}{l}0.72 \\
0.60\end{array}$ & $\begin{array}{l}3.05 \\
2.08\end{array}$ & $\begin{array}{l}0.03 \\
0.02\end{array}$ & $\begin{array}{l}1.78 \\
1.30\end{array}$ & $\begin{array}{l}0.84 \\
1.03\end{array}$ & $\begin{array}{l}1.60 \\
1.60\end{array}$ & $\begin{array}{l}1.33 \\
1.05\end{array}$ & 2.21 & $\begin{array}{l}2.43 \\
1.90\end{array}$ & 0.13 & $\begin{array}{l}0.0 \\
0.0\end{array}$ & $\begin{array}{l}0.64 \\
0.35\end{array}$ & $\begin{array}{l}0.46 \\
0.40\end{array}$ & $\begin{array}{l}0.49 \\
0.54\end{array}$ & $\begin{array}{l}0.94 \\
0.70\end{array}$ & $=$ & 100.14 & 0.45 & 0.12 & 99.67 \\
\hline $\begin{array}{l}28,0 \mathrm{CC}, 29-31 \\
30-1,35-37\end{array}$ & $\begin{array}{l}2665.0 \\
275.9\end{array}$ & $\begin{array}{l}\text { Porcellanite (C) } \\
\text { Porcellanite (C) }\end{array}$ & $\begin{array}{l}80.13 \\
84.02\end{array}$ & $\begin{array}{l}0.33 \\
0.27\end{array}$ & $\begin{array}{l}5.77 \\
4.10\end{array}$ & $\begin{array}{l}2.68 \\
2.55\end{array}$ & $\begin{array}{l}0.60 \\
0.54\end{array}$ & $\begin{array}{l}2.08 \\
2.01\end{array}$ & $\begin{array}{l}0.02 \\
0.01\end{array}$ & $\begin{array}{l}1.30 \\
0.92\end{array}$ & $\begin{array}{l}1.03 \\
0.86\end{array}$ & $\begin{array}{l}1.60 \\
1.13\end{array}$ & $\begin{array}{l}1.05 \\
0.77\end{array}$ & $\begin{array}{l}2.111 \\
1.96\end{array}$ & $\begin{array}{l}1.90 \\
1.62\end{array}$ & ${ }_{0.23}^{0.23}$ & 0.60 & 0.54 & -.40 & - & - & $=$ & 99.58 & -3 & - & $\begin{array}{l}99.58 \\
99.01\end{array}$ \\
\hline $35-3,26-30$ & 326.3 & Siliceous clayst, (Q) & 65.54 & 0.58 & 12.71 & 4.59 & 1.57 & 3.02 & 0.04 & 2.25 & 1.85 & 2.70 & 2.44 & 2.76 & 2.83 & 0.21 & 0.25 & 0.35 & 0.41 & 0.39 & 0.41 & - & 100.31 & 0.21 & 0.08 & 100.02 \\
\hline \multicolumn{27}{|l|}{ Site 472} \\
\hline $1-2,60-65$ & 2.1 & Clay & 50.78 & 0.70 & 14.80 & 6.99 & 0.07 & 6.92 & 0.78 & 3.22 & 1.85 & 4.69 & 2.87 & 5.73 & 4.45 & 0.02 & 0.0 & 0.40 & 0.74 & 2.88 & 0.08 & - & 100.98 & 0.04 & 0.65 & 100.29 \\
\hline $6-3,80-85$ & 47.3 & Clayey diatom ooze (A) & 62.89 & 0.34 & 7.54 & 5.05 & 0.71 & 4.34 & 0.16 & 2.67 & 1.26 & 4.69 & 1.99 & 3.83 & 4.92 & 0.12 & 0.0 & 0.27 & 1.50 & 2.91 & 0.32 & - & 100.46 & 0.16 & 0.65 & 99.65 \\
\hline \multicolumn{27}{|l|}{ Site 473} \\
\hline 13-2, 90-95 & 107.4 & Clay & 53.85 & 0.70 & 15.83 & 6.00 & 1.29 & 4.71 & 0.17 & 2.62 & 1.85 & 3.70 & 3.29 & 3.85 & 4.34 & 0.05 & 0.0 & 0.87 & 1.08 & 1.56 & 0.67 & - & 100.43 & 0.34 & 0.35 & 99.74 \\
\hline $28-1,2-5$ & 238.0 & Porcellanite (C) & 74.83 & 0.34 & 7.58 & 3.99 & 1.00 & 2.99 & 0.04 & 1.79 & 1.44 & 1.97 & 1.66 & 2.22 & 2.99 & 0.32 & 0.0 & 0.14 & 0.29 & 0.42 & 0.23 & - & 100.25 & 0.12 & 0.09 & 100.04 \\
\hline \multicolumn{27}{|c|}{ 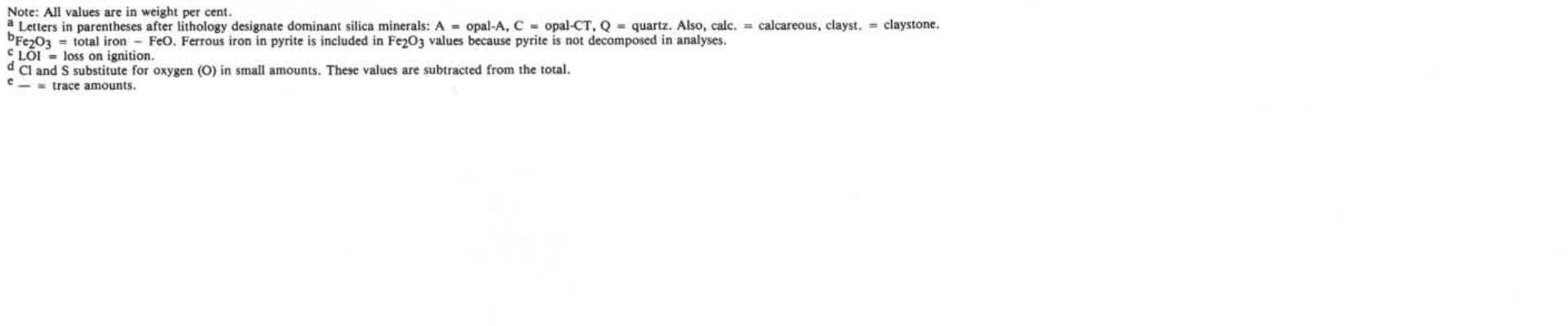 } \\
\hline
\end{tabular}


Table 2. Soluble and insoluble silica contents of Leg 63 siliceous rocks.

\begin{tabular}{|c|c|c|c|c|c|c|c|c|c|c|c|c|c|c|c|c|c|}
\hline \multirow{3}{*}{$\begin{array}{c}\text { Sample } \\
\text { (interval in } \mathrm{cm} \text { ) }\end{array}$} & \multirow{3}{*}{$\begin{array}{l}\text { Total } \\
\mathrm{SiO}_{2}\end{array}$} & \multirow{3}{*}{$\begin{array}{c}\text { Insoluble } \\
\mathrm{SiO}_{2}\end{array}$} & \multicolumn{15}{|c|}{ Soluble $\mathrm{SiO}_{2}, \mathrm{Al}_{2} \mathrm{O}_{3}$ and $\mathrm{Fe}_{2} \mathrm{O}_{3}$ determined in sodium extracts ${ }^{\mathrm{b}}$} \\
\hline & & & \multicolumn{3}{|c|}{$1+11$} & \multicolumn{3}{|c|}{ III + IV } & \multicolumn{3}{|c|}{$V+V I$} & \multicolumn{3}{|c|}{$\mathrm{VII}+\mathrm{VIII}$} & \multicolumn{3}{|c|}{$\mathrm{IX}+\mathrm{X}$} \\
\hline & & & $\mathrm{SiO}_{2}$ & $\mathrm{Al}_{2} \mathrm{O}_{3}$ & $\mathrm{Fe}_{2} \mathrm{O}_{3}$ & $\mathrm{SiO}_{2}$ & $\mathrm{Al}_{2} \mathrm{O}_{3}$ & $\mathrm{Fe}_{2} \mathrm{O}_{3}$ & $\mathrm{SiO}_{2}$ & $\mathrm{Al}_{2} \mathrm{O}_{3}$ & $\mathrm{Fe}_{2} \mathrm{O}_{3}$ & $\mathrm{SiO}_{2}$ & $\mathrm{Al}_{2} \mathrm{O}_{3}$ & $\mathrm{Fe}_{2} \mathrm{O}_{3}$ & $\mathrm{SiO}_{2}$ & $\mathrm{Al}_{2} \mathrm{O}_{3}$ & $\mathrm{Fe}_{2} \mathrm{O}_{3}$ \\
\hline $467-19-5,115-120$ & 45.32 & 5.23 & 11.50 & 0.07 & 0.06 & 4.50 & 0.14 & 0.03 & 3.25 & 0.06 & 0.01 & 2.70 & 0.07 & 0.01 & n.d. & n.d. & n.d. \\
\hline $467-40-3,12-16$ & 49.08 & 6.98 & 6.90 & 0.09 & 0.04 & 3.40 & 0.14 & 0.03 & 3.40 & 0.10 & 0.01 & 1.35 & 0.06 & 0.02 & n.d. & n.d. & n.d. \\
\hline $467-69-1,130-134$ & 54.82 & 5.37 & 20.90 & 0.06 & 0.04 & 4.70 & 0.11 & 0.03 & 2.30 & 0.08 & 0.01 & 1.44 & 0.04 & 0.02 & n.d. & n.d. & n.d. \\
\hline $467-78-1,61-62$ & 91.71 & 58.78 & 11.80 & 0.08 & 0.08 & 6.10 & 0.04 & 0.02 & 4.50 & 0.03 & 0.01 & 3.95 & 0.02 & 0.01 & n.d. & n.d. & n.d. \\
\hline $467-79-1,30-31$ & 95.67 & 77.82 & 8.70 & 0.03 & 0.06 & 4.40 & 0.04 & 0.02 & 3.00 & 0.03 & 0.01 & 3.40 & 0.03 & 0.01 & n.d. & n.d. & n.d. \\
\hline $467-92-1,116-118$ & 91.74 & 62.67 & 10.50 & 0.08 & 0.06 & 4.80 & 0.07 & 0.02 & 2.95 & 0.03 & 0.01 & 3.10 & 0.03 & 0.01 & n.d. & n.d. & n.d. \\
\hline $467-98-2,44-46$ & 34.93 & 10.09 & 3.40 & 0.08 & 0.06 & 2.50 & 0.04 & 0.01 & 2.50 & 0.03 & 0.01 & 1.30 & 0.04 & 0.02 & n.d. & n.d. & n.d. \\
\hline $469-24-3,6-10$ & 57.63 & 5.24 & 5.90 & 0.10 & 0.05 & 4.80 & 0.18 & 0.03 & 3.40 & 0.11 & 0.01 & 2.45 & 0.10 & 0.01 & n.d. & n.d. & n.d. \\
\hline $469-36-1,62-66$ & 73.33 & 2.95 & 25.00 & 0.07 & 0.03 & 7.90 & 0.08 & 0.01 & 4.00 & 0.10 & 0.02 & 2.15 & 0.09 & 0.02 & n.d. & n.d. & n.d. \\
\hline $470-11-4,110-115$ & 71.00 & 3.44 & 23.40 & 0.04 & 0.04 & 10.00 & 0.04 & 0.03 & 6.40 & 0.04 & 0.01 & 5.00 & 0.04 & 0.02 & 3.82 & 0.04 & 0.02 \\
\hline $471-10-5,120-125$ & 68.37 & 3.22 & 15.80 & 0.04 & 0.05 & 13.60 & 0.04 & 0.02 & 5.55 & 0.05 & 0.01 & 6.40 & 0.04 & 0.01 & 5.04 & 0.08 & 0.03 \\
\hline $471-17-2,120-125$ & 71.00 & 3.44 & 23.40 & 0.04 & 0.04 & 10.00 & 0.04 & 0.03 & 6.40 & 0.04 & 0.01 & 5.00 & 0.04 & 0.02 & 3.82 & 0.04 & 0.02 \\
\hline $471-18, C C, 16-20$ & 87.96 & 3.31 & 28.20 & 0.02 & 0.03 & 16.20 & 0.08 & 0.03 & n.d. & n.d. & n.d. & n.d. & n.d. & n.d. & n.d. & n.d. & n.d. \\
\hline $471-19, C C, 13-17$ & 89.77 & 5.96 & 26.20 & 0.01 & 0.03 & 16.00 & 0.10 & 0.01 & n.d. & n.d. & n.d. & n.d. & n.d. & n.d. & n.d. & n.d. & n.d. \\
\hline $471-23-1,0-5$ & 76.75 & 3.57 & 24.20 & 0.02 & 0.03 & 8.10 & 0.16 & 0.02 & n.d. & n.d. & n.d. & n.d. & n.d. & n.d. & n.d. & n.d. & n.d. \\
\hline $471-28, C C, 29-31$ & 80.13 & 4.89 & 26.10 & 0.03 & 0.03 & 6.50 & 0.11 & 0.01 & n.d. & n.d. & n.d. & n.d. & n.d. & n.d. & n.d. & n.d. & n.d. \\
\hline $471-30-1,35-37$ & 84.02 & 6.31 & 31.00 & 0.04 & 0.03 & 7.00 & 0.10 & 0.03 & n.d. & n.d. & n.d. & n.d. & n.d. & n.d. & n.d. & n.d. & n.d. \\
\hline $471-35-3,26-30$ & 65.54 & 12.28 & 5.20 & 0.14 & 0.03 & 2.00 & 0.08 & 0.02 & n.d. & n.d. & n.d. & n.d. & n.d. & n.d. & n.d. & n.d. & n.d. \\
\hline $473-28-1,2-5$ & 74.83 & 5.69 & 25.80 & 0.03 & 0.03 & 6.00 & 0.10 & 0.01 & n.d. & n.d. & n.d. & n.d. & n.d. & n.d. & n.d. & n.d. & n.d. \\
\hline
\end{tabular}

Note: All values are in weight per cent; n.d. = not determined.

a See Table 1 for lithologies of samples.

$\mathrm{b}$ Roman numerals designate the numbers of successive extractions. Thus values listed under analyses $1+\mathrm{II}$ are sums of the first and second treatments. The difference between total silica values and the insoluble + soluble silica values is an estimate of $\mathrm{SiO}_{2}$ contained in aluminosilicates.

Fisher, R. V., and Charlton, D. W., 1976. Mid-Miocene Blanca Formation, Santa Cruz Island, California. In Howell, D. G. (Ed.), Aspects of the Geologic History of the California Continental Borderland: Am. Assoc. Petrol. Geol. Misc. Publ. Pac. Sec., 24:228-240.

Fournier, R. O., 1973. Silica in thermal waters: laboratory and field investigations. International Symposium on Hydrogeochemistry and Biochemistry, Tokyo, 1970, Proc.: Washington, D.C. (Clarke Co.), 1:122-139.

Friedman, I., and Murata, K. J., 1979. Origin of dolomite in Miocene Monterey Shale and related formations in the Temblor Range, California. Geochim. Cosmochim. Acta, 43:1357-1365.

Garrison, R. E., 1972. Inter- and intrapillow limestones of the Olympic Peninsula, Washington. J. Geol., 80:310-322.

1974. Radiolarian cherts, pelagic limestones, and igneous rocks in eugeosynclinal assemblages. In Hsü, K. J., and Jenkyns, H. C. (Eds.), Pelagic Sediments: On Land and Under the Sea: Spec. Publ. Int. Assoc. Sedimentol., 1:367-399.

1976. Neogene diatomaceous sedimentation in east Asia: a review with recommendations for further study. U.N. ESCAP, CCOP Tech. Bull., 9:57-69.

Garrison, R. E., Rowland, S. M., Horan, L. J., et al., 1975. Petrology of siliceous rocks recovered from marginal seas of the western Pacific, Leg 31, Deep Sea Drilling Project. In Karig, D. E., Ingle, J. C., Jr., et al., Init. Repts. DSDP, 31: Washington (U.S. Govt. Printing Office), 519-530.

Grechin, V. I., 1971. Miocene siliceous rocks of western Kamchatka. Lithol. Miner. Resour., 4:117-123.

1972. On methods of studying katagenetic transformations in siliceous rocks (as exemplified by the Miocene of Kamchatka and Sakhalin). Lithol. Miner. Resour., 4:147-151.

, 1976. Miocene deposits of west Kamchatka (sedimentation and catagenesis). Tr. Inst. Geol. Akad. Nauk SSSR, 282.

Hayes, D. E., Frakes, L. A. et al., 1975. Init. Repts. DSDP, 28 : Washington (U.S. Govt. Printing Office).

Hein, J. R., O'Neil, J. R., and Jones, M. G., 1979. Origin of authigenic carbonates in sediment from the deep Bering Sea. Sedimentology, 26:681-705.

Hein, J. R., Scholl, D. W., Barron, J. A., et al., 1978. Diagenesis of late Cenozoic diatomaceous deposits and formation of the bottom simulating reflector in the southern Bering Sea. Sedimentology, 25: $155-181$.

Hein, J. R., Vanek, E., and Allen, M. A., 1979. X-ray mineralogy and diagenesis. In Cook, H. E. (Ed.), Geologic Studies of the Point Conception Deep Stratigraphic Test Well OCS-CAL 78-164 No. 1, Outer Continental Shelf, Southern California, United States: U.S. Geol. Surv. Open-File Rep., 79-1218, pp. 79-96.
Helenes, J., and Ingle,J. C., Jr., 1979. Stratigraphy, foraminifera, and depositional environments of the Miocene Tortugas Formation, Baja California, Mexico: a preliminary report and guide. In Abbot, P. L., and Gastil, R. G. (Eds.), Baja California GeologyField Guide and Papers: San Diego State University, (Department of Geological Sciences), pp. 83-88.

Hollister, C. D., Craddock, C., et al., 1976. Init. Repts. DSDP, 35: Washington (U.S. Govt. Printing Office).

Iijima, A., Matsumoto, R., and Tada, R., in press. Zeolitic and silica diagenesis and sandstone petrography at Sites 438 and 439, DSDP/IPOD Leg 57 off Samriku, Northwest Pacific. In Scientific Party, Init. Repts. DSDP, 56, 57, Pt. 2: Washington (U.S. Govt. Printing Office), 1143-1158.

Iijima, A., and Tada, R., in press. Silica diagenesis of Neogene diatomaceous and volcaniclastic sediments in northern Japan. Sedimentology.

Iijima, A., and Utada, M., 1966. Zeolites in sedimentary rocks, with reference to the depositional environments and zonal distributtion. Sedimentology, 7:327-357.

1972. A critical review on the occurrence of zeolites in sedimentary rocks in Japan. Jpn. J. Geol. Geogr., 42:61-84.

Ingle, J. C., Jr., 1973. Summary comments on Neogene biostratigraphy, physical stratigraphy, and paleoceanography in the marginal northeastern Pacific Ocean. In Kulm, L. D., von Huene, R., et al., Init. Repts. DSDP, 18: Washington (U.S. Govt. Printing Office), 949-959.

1980. Cenozoic paleobathymetry and depositional history of selected sequences within the southern California Continental Borderland. Cushman Found. Spec. Publ., 19:163-195.

Ingle, J.C., Jr., Garrison, R. E., and Pisciotto, K. A., 1978. Origin, distribution, and diagenetic modifications of Neogene diatomaceous sediments in the circum-Pacific region. Second circum-Pacific Energy Conference Abstract with Program, Honolulu, pp. 34-35. (Abstract)

Isaacs, C. M., 1979. Lateral diagenesis in Monterey Shale, Santa Barbara Coast, California. Bull. Am. Assoc. Petrol. Geol., 63:473. (Abstract)

1980. Diagenesis in the Monterey Formation examined laterally along the coast near Santa Barbara, California [Ph.D. thesis]. Stanford University.

Jones, J. B., and Segnit, E. R., 1971. The nature of opal. I. Nomenclature and constituent phases. J. Geol. Soc. Aust., 18:57-68.

Kastner, M., 1976. Diagenesis of basal sediments and basalts of Sites 322 and 323, Leg 35, Bellinghausen abyssal plain. In Hollister, C. D., Craddock, C., et al., Init. Repts. DSDP, 35: Washington (U.S. Govt. Printing Office), 513-528. 

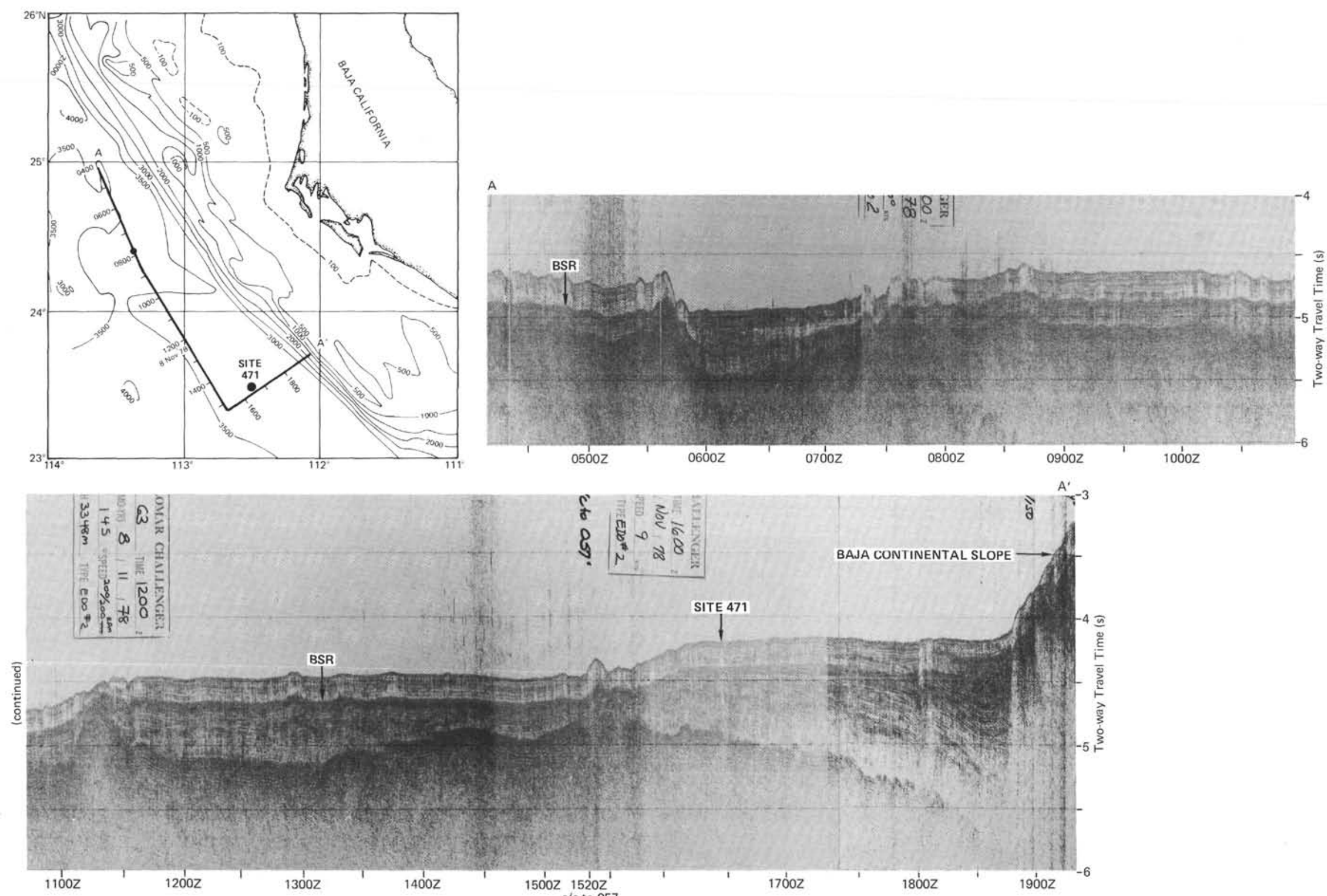

Figure 8. Challenger seismic section approaching Site 471, showing prominent bottom-simulating reflector (BSR) corresponding to the transition from opal-A diatom ooze to opal-CT porcellanite and chert. (Bathymetric contours are in meters. Time marks on seismic line are in hours [Zulu].) 


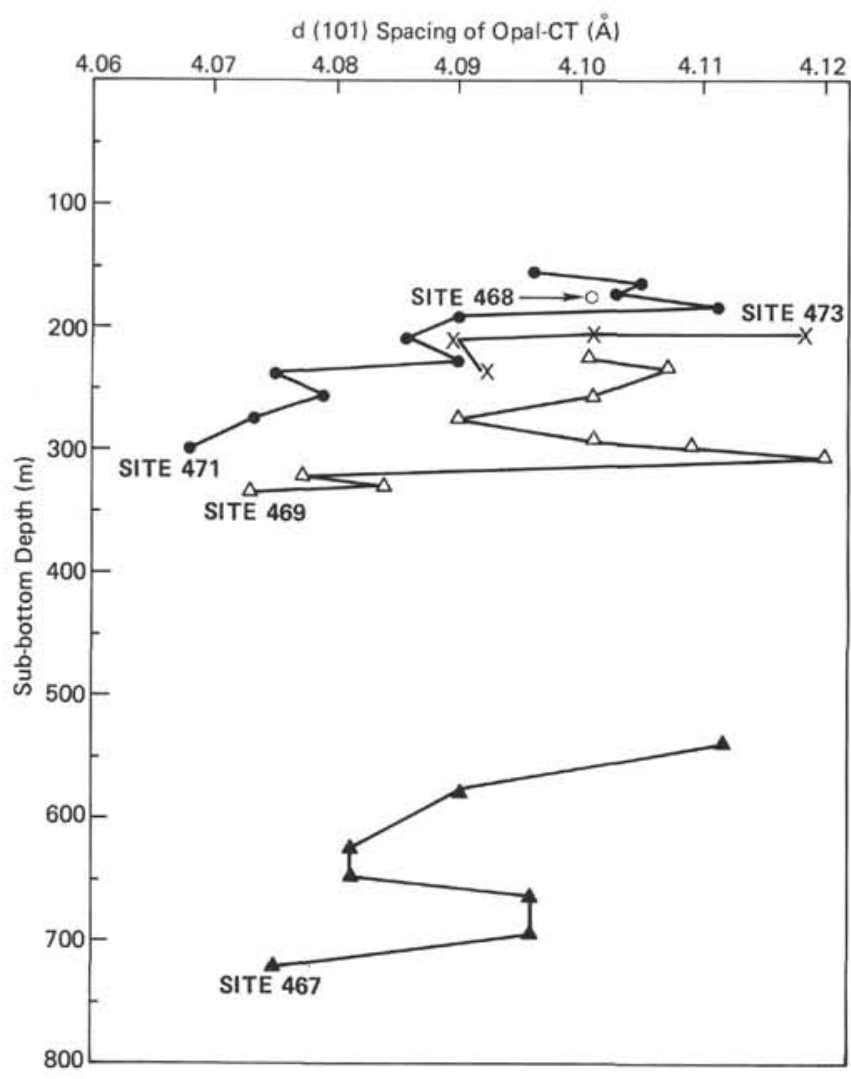

Figure 9. Four d(101)-spacing curves of opal-CT at Leg 63 sites.

Table 3. Depths of burial of silica zones and present thermal gradients at Leg 63 sites and at the Point Conception Deep Stratigraphic Test Well (Fig. 1).

\begin{tabular}{lcc}
\hline \multicolumn{1}{c}{ Site } & $\begin{array}{c}\text { Depth to Top } \\
\text { Opal-CT Zone } \\
(\mathrm{m})\end{array}$ & $\begin{array}{c}\text { Present Thermal } \\
\text { Gradient } \\
\left({ }^{\circ} \mathrm{C} / \mathrm{km}\right)\end{array}$ \\
\hline OCS CAL 78-164 No. 1 & 1001 & $\sim 48(\mathrm{~min})$ \\
467 & 5538 & $\sim 63(\mathrm{~min})$ \\
468 & $184(?)$ & nd \\
469 & 235 & nd \\
470 & - & nd \\
471 & 161 & $70-151$ \\
472 & - & $\sim 141$ \\
473 & 203 & $64-160$ \\
\hline
\end{tabular}

Note: $-=$ no opal-CT encountered; nd $=$ no data.

Kastner, M., Keene, J.B., and Gieskes, J. M., 1977. Diagenesis of siliceous oozes. I. Chemical controls on the rate of opal-A diagenesis-an experimental study. Geochim. Cosmochim. Acta, 41:1041-1059.

Keene, J. B., 1975. Cherts and porcellanites from the North Pacific, DSDP Leg 32. In Larson, R. L., Moberly, R. J., Jr., et al., Init. Repts. DSDP, 32: Washington (U.S. Govt. Printing Office), 429-507.

Khvorova, I. V., 1968. Deposition of silica in geosynclinal areas of the past. Sedimentation and Ore Deposits of the Ancient Volcanic Regions: Tr. Inst. Geol. Ak Nauk, SSSR, 1:9-136. (In Russian)

McCulloh, T. H., and Beyer, L. A., 1979, Geothermal gradients. In Cook, H. E. (Ed.), Geologic Studies of the Point Conception Deep Stratigraphic Test Well, Outer Continental Shelf, Southern California, United States: U.S. Geol. Surv. Open-File Rep., 79-1218: 43-48.
McLean, H., Howell, D. G., and Vedder, J. G., 1976. Miocene strata on Santa Cruz and Santa Rosa Islands-a reflection of tectonic events in the Southern California Borderland. In Howell, D. G. (Ed.), Aspects of the Geologic History of the California Continental Borderland: Pac. Sec. Am. Assoc. Petrol. Geol. Misc. Publ., 24:241-255.

Minch, J. C., Gastil, G., Fink, W., et al., 1976. Geology of the Vizcaino Peninsula. In Howell, D. G. (Ed.), Aspects of the Geologic History of the California Continental Borderland: Pac. Sec. Am. Assoc. Petrol. Geol. Misc. Publ., 24:136-195.

Mitsui, K., and Taguchi, K., 1977. Silica mineral diagenesis in Neogene Tertiary shales in the Tempoku district, Hokkaido, Japan. J. Sediment. Petrol., 47:158-167.

Mizutani, S., 1966. Transformation of silica under hydrothermal conditions. J. Earth Sci. Nagoya Univ., 14:56-88.

1967. Kinetic aspects of diagenesis of silica in sediments. $J$. Earth Sci. Nagoya Univ., 15:99-111. 1970. Silica minerals in the early stage of diagenesis. Sedimentology, 15:419-436.

1977. Progressive ordering of cristobalitic silica in the early stage of diagenesis. Contrib. Mineral. Petrol., 61:129-140.

Murata, K. J., Dibblee, T. W., Jr., and Drinkwater, J. L., 1979. Thermal effects of large bodies of intrusive serpentinite on overlying Monterey Shale, southern Diablo Range, Cholame area, California. U.S. Geol. Surv. Prof. Pap. 1082.

Murata, K. J., Friedman, I., and Cremer, M., 1972. Geochemistry of diagenetic dolomites in Miocene marine formations of California and Oregon. U.S. Geol. Surv. Prof. Pap. 724-C.

Murata, K. J., Friedman, I., and Madsen, B. M., 1969. Isotopic composition of diagenetic carbonates in marine Miocene formations of California and Oregon. U.S. Geol. Surv. Prof. Pap. 614-B.

Murata, K. J., and Larson, R. R., 1975. Diagenesis of Miocene siliceous shales, Temblor Range, California. J. Res. U.S. Geol. Surv., 3:553-566.

Murata, K. J., and Nakata, J. K., 1974. Cristobalitic stage in the diagenesis of diatomaceous shale. Science, 184:567-568.

Murata, K. J., and Randall, R. G., 1975. Silica mineralogy and structure of the Monterey Shale, Temblor Range, California. J. Res. U.S. Geol. Surv., 3:567-572.

Orr, W. N., 1972. Pacific Northwest siliceous phytoplankton. Palaeogeogr., Palaeoclim., Palaeoecol., 12:95-114.

Park, C. F., Jr., 1942. Manganese resources of the Olympic Peninsula, Washington-a preliminary report. Bull. U.S. Geol. Surv., 931-R:435-457.

1946. The spilite and manganese problems of the Olympic Peninsula, Washington. Am. J. Sci., 244:305-323.

Pisciotto, K. A., 1978. Basinal sedimentary facies and diagenetic aspects of the Monterey Shale, California [Ph.D. thesis]. University of California, Santa Cruz.

1979. Deduction of past geothermal gradients in Neogene siliceous rocks in the circum-Pacific region. Am. Assoc. Pet. Geol. Bull., 63:510. (Abstract)

Sawamura, K., and Uemura, F., 1973. Notes on diatomaceous carbonate nodules in the Neogene Tertiary system of Ajigasawa area, Aomori Prefecture. Jpn. Geol. Surv. Bull., 24:185-192.

Scholl, D. W., and Creager, J. S., 1973. Geologic synthesis of Leg 19 (DSDP) results: Far North Pacific, Aleutian Ridge, and Bering Sea. In Creager, J. S., Scholl, D. W., et al., Init. Repts. DSDP, 19: Washington (U.S. Govt. Printing Office), 897-913.

Takahashi, J., 1922. The marine Kerogen Shales from the oil fields of Japan, a contribution to the study of the origin of petroleum. Sci. Rep. Tohoku Imp. Univ., Ser. 3, 1:63-156.

Taliaferro, N. L., 1934. Contraction phenomena in cherts. Bull. Geol. Soc. Am., 45:189-232.

Watanabe, M., 1970. Carbonate concretions in the Neogene Tertiary system, northeast Japan. Sci. Rep. Tohoku Imp. Univ., Ser. 3, 11:69-112.

Weaver, D. W., Doerner, D. P., and Nolf, B., 1969. Geology of the northern Channel Islands, California. Pac. Sec. Am. Assoc. Petrol. Geol.: Soc. Econ. Paleontol. Mineral. Spec. Publ.

Zalmanzon, E. S., 1957. Determination of forms of some elements and analysis of clay colloid fraction. In Strackov, N. M. (Ed.), Methods of Investigation of Sedimentary Rocks: Moscow (Gosgeoltekhizdat), 2:53-69. 

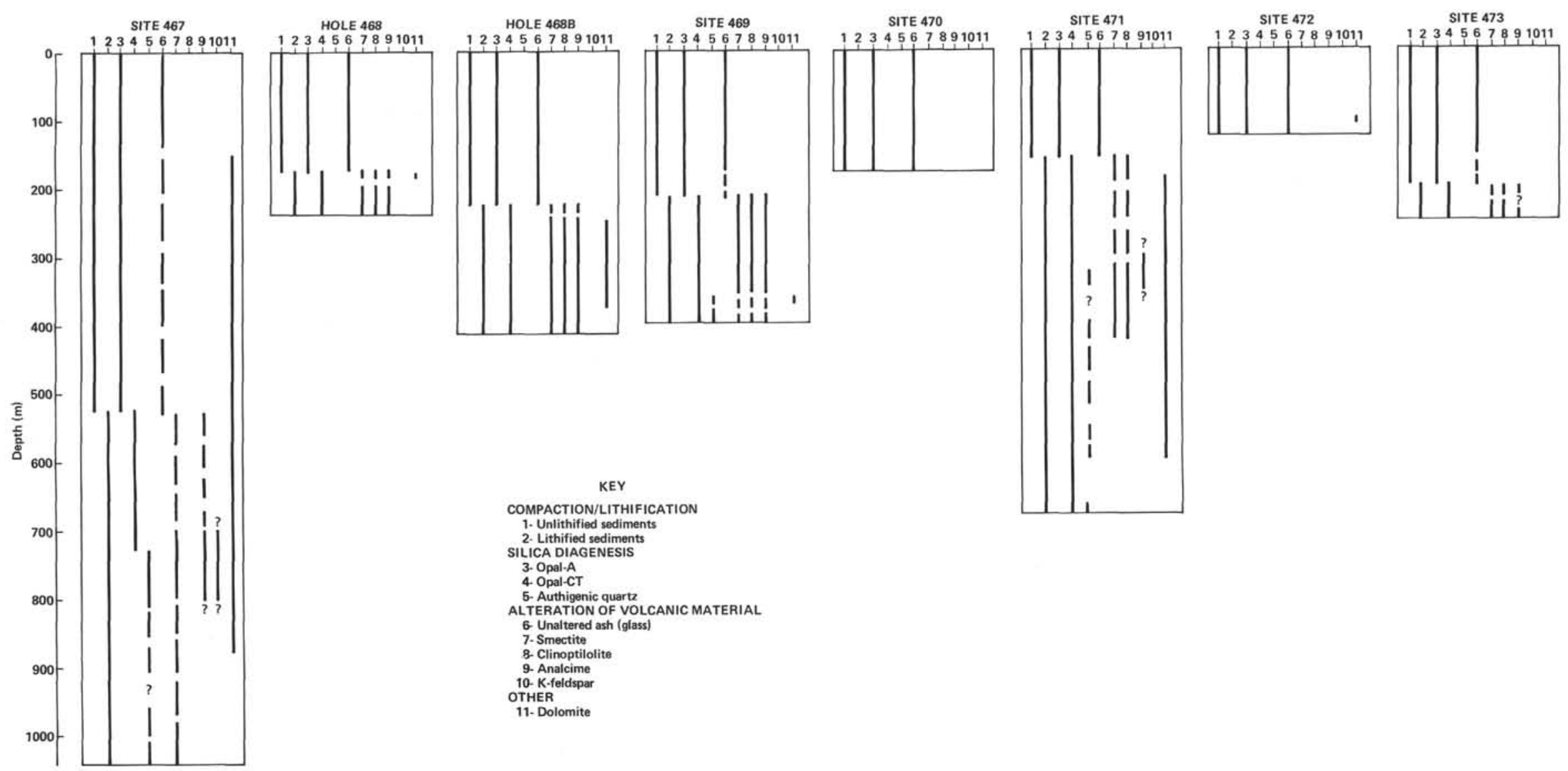

Figure 10. Summary of diagenetic minerals and trends at Leg 63 sites. (Vertical lines show distributions of diagenetic minerals and parameters.)

COMPACTION/LITHIFICATION

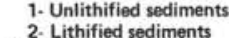

SILICA DIAGENESIS

3. Opal-A
4. Opal-CT

55. Authigenic quart

6. Unaltered ash (glass)

7. Smectite

9. Analcime
10.- K. feldspar

11- Dolomite 